\title{
THE
}

\section{Evaluating Native American Bird Use and Bird Assemblage Variability along the Oregon Coast}

Kristine M. Bovy

University of Rhode Island, kbovy@uri.edu

Madonna L. Moss

Jessica E. Watson

Frances J. White

Timothy T. Jones

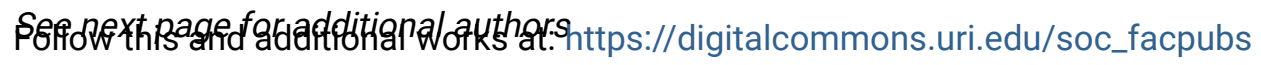

The University of Rhode Island Faculty have made this article openly available. Please let us know how Open Access to this research benefits you.

This is a pre-publication author manuscript of the final, published article.

Terms of Use

This article is made available under the terms and conditions applicable towards Open Access Policy Articles, as set forth in our Terms of Use.

\section{Citation/Publisher Attribution}

Bovy, K. M., Moss, M. L., Watson, J. E., White, F. J., Jones, T. T., Ulrich, H. A., \& Parrish, J. K. (2019). Evaluating Native American Bird Use and Bird Assemblage Variability along the Oregon Coast. The Journal of Island and Coastal Archaeology, 14(3), 301-336. doi: 10.1080/15564894.2018.1457105 Available at: https://doi.org/10.1080/15564894.2018.1457105 
Authors

Kristine M. Bovy, Madonna L. Moss, Jessica E. Watson, Frances J. White, Timothy T. Jones, Heather A. Ulrich, and Julia K. Parrish

This article is available at DigitalCommons@URI: https://digitalcommons.uri.edu/soc_facpubs/35 


\begin{abstract}
Native American use of birds on the Oregon coast is not well known and has never been synthesized to present a regional understanding. We rectify this by analyzing data from 26 zooarchaeological assemblages, including three previously unpublished bird assemblages: Umpqua/Eden (35DO83), Whale Cove (35LNC60), and the Dunes Site (35CLT27). We employ a series of non-parametric randomization tests to directly evaluate patterns of taxonomic diversity, correlations with nearby breeding colonies, and broader procurement strategies discussed in ethnohistorical accounts. We compare the assemblages to contemporary surveys of naturally beached birds as observed by COASST (Coastal Observation Seabird Survey Team) and evaluate whether archaeological specimens were scavenged from the beach. While $71 \%$ of the identified bird remains belong to just three families (Anatidae, Alcidae, and Procellariidae), closer analysis reveals the incredible diversity of birds used by Oregon coast Native Americans. The assemblages vary considerably in terms of taxonomic diversity and composition, leading us to conclude that people used birds opportunistically, likely incorporating multiple strategies, including hunting, collecting beached carcasses and targeting cormorant colonies. We hope that the methods and approaches employed here will inspire other archaeologists to devote more attention to bird assemblages, and how their study can inform conservation efforts.
\end{abstract}

\title{
INTRODUCTION
}

Even though bird bones are common in Oregon (USA) coast archaeological sites, ethnographic information regarding the use of birds by local Native Americans is extremely limited (Hall 2001:20-22; Minor and Toepel 1986:63). Beyond brief mentions in early reports (e.g., Drucker 1939; Kroeber 1939), bird use in this region has not been widely discussed. From the Lewis and Clark expedition, we know that birds were so numerous - and loud — that at least some of the 
explorers could not sleep for the noise (Moulton 1990:21). Suttles (1990:27) suggests birds were more important in the Pacific Northwest Coast than often assumed, with waterfowl "vastly more important" than terrestrial birds. The degree to which different birds were hunted for food, their eggs gathered, their feathers and skins used to make clothing or regalia, or their bones made into tools is not well documented. Birds have received less attention by zooarchaeologists in the Pacific Northwest Coast than fish or mammals, perhaps because they are often less abundant in these sites (Butler and Campbell 2004; Lindsay 1995).

Yet we now have an adequate number of systematically analyzed bird assemblages to begin outlining general patterns of bird use and raising questions to direct future research. Analyses of bird bones can provide information on pre-contact dietary practices, site seasonality, foraging locations, hunting and processing strategies, and dynamic coastal environments. We examine which birds were used, how they were likely obtained, and how taxonomic abundance and diversity vary by location, using original data from Umpqua/Eden (35DO83), Whale Cove (35LNC60), and the Dunes Site (35CLT27) and published data from 23 other Oregon coast sites. The methods and observations from these assemblages will be relevant to researchers studying birds in coastal settings worldwide.

\section{BACKGROUND AND CONTEXT}

\section{Oregon Coast Environments and Cultures}

The Oregon coast is located within the southern part of the Pacific Northwest Coast culture area, which extends from Icy Bay, Alaska, to northern California (Moss 2011). The 480 km-long coastline consists of rocky shorelines, headlands, and sandy beaches. Oregon is part of the Northern California Current Ecoregion, a transitional zone between colder subarctic waters of the Gulf of Alaska and subtropical waters off Baja California (OCMP 2016). The continental 
shelf off Oregon is narrower, steeper, and deeper than average, contributing to a pelagic zone that is only 14 to $64 \mathrm{~km}$ offshore (Byrne 1962:67). Seasonal upwelling is typical (Bograd et al. 2009), with a switch from winter downwelling (on-shore flow of surface waters associated with wind direction and storm events) to summer upwelling (off-shore flow of surface waters bringing cold, nutrient-rich bottom waters to the surface). Timing of this spring transition and intensity of the upwelling season affect coastal productivity (Barth et al. 2007), including the reproductive success and mortality rates of coastal seabirds (Parrish et al. 2007).

In the early 1800 s, the Oregon coast was occupied by diverse Native American tribes, including (from north to south) various bands of Chinook, Clatsop, Tillamook, Alsea, Siuslaw, Umpqua, Coos, Coquille, Tututni, and Tolowa (Figure 1). Linguistic data suggest that representatives of three language phyla (Na-Dene, Salishan, and Penutian) and at least five language families (Athapaskan, Chinookan, Alsean, Siuslaw, and Coos) were spoken (Thompson and Kinkade 1990). Cultural differences among Oregon coast groups are due to different adaptations to various Oregon coast environments and diverse origins. People were in central Oregon by at least 14,000 years ago (Jenkins et al. 2014), though the earliest date for a coastal archaeological site is ca. 9000 cal BP (35CU67; Moss and Erlandson 1998). The relative scarcity of early sites along the Oregon coast is due to post-glacial sea level rise, episodic tectonic subsidence, tsunamis, landslides, severe coastal erosion, accumulation of extensive dunes during the middle and late Holocene, and the evolution of former estuaries into lakes (Lyman 1991; Moss and Erlandson 2008). The most substantial bird assemblages studied thus far date to the late Holocene (3000 to $400 \mathrm{cal} \mathrm{BP}$ ); this is the time period on which we focus.

\section{Birds of the Oregon Coast}


A diversity of birds is found on the Oregon coast, including seabirds, shorebirds, and waterfowl. Table 1 summarizes the pertinent life history information for some of the most common taxa found in archaeological sites in the region. We organize these taxa into three categories based on geographic distribution and natural history: waterfowl (ducks/geese), coastal seabirds that nest along the Oregon coastline, and pelagic (open water) seabirds nesting outside the Pacific Northwest and migrating into Oregon waters (predominantly during the non-breeding season).

\section{Waterfowl (Anatids)}

Anatidae is a large family, with 7 species of geese and swans (Anserinae), 10 dabbling ducks (Anatini), 5 pochards/bay ducks (Aythini), 11 sea ducks (Mergini) and the Ruddy Duck (Oxyura jamaicensis) present in coastal Oregon. Dabbling ducks/geese feed on plants or small mollusks in a variety of shallow water and terrestrial habitats. Diving ducks (pochards and sea ducks) generally winter in the Pacific Northwest, and migrate to and from their breeding grounds in northern regions or interior lakes in the spring and fall. Diving ducks, such as scoters, feed on fish and shellfish in deeper waters including estuaries and exposed coastal habitats, and can be found in large congregations.

Nesting Seabirds

The Common Murre (Uria aalge) is the largest (800-1300 g) and most abundant alcid breeding along the Pacific Northwest Coast, comprising over half of all seabirds nesting in Oregon (Naughton et al. 2007a:5). Breeding commences in April, with eggs appearing in May (Gladics et al. 2015). Breeders remain on-colony until July, and then disperse throughout the nearshore ecosystem of the Pacific Northwest (Gladics et al. 2015). Following breeding, Pacific Northwest murres have a flightless molt period in September-November (Jones et al. 2017). Four other alcid species breed within the nearshore ecosystem of Oregon: Tufted Puffin (Fratercula cirrhata), 
Rhinoceros Auklet (Cerorhinca monocerata), Cassin's Auklet (Ptychoramphus aleuticus), and Pigeon Guillemot (Cepphus columba), albeit all in much lower numbers than murres (Naughton et al. 2007a). During the fall post-breeding season, larger numbers of both auklet species can be found in Oregon coastal shelf waters, as tens to hundreds of thousands of individuals from Washington and British Columbia colonies migrate south (Gaston and Dechesne 1996; Manuwal and Thoresen 2011).

Cormorants include the Double-crested (Phalacrocorax auritus), Brandt's ( $P$. penicillatus) and Pelagic Cormorant (P. pelagicus), all of which nest on rocky spires, outcroppings and predator-free offshore islands. Double-crested cormorants also nest within estuarine systems, on islands throughout the Columbia River system, and in a variety of inland freshwater lakes (Wiese et al. 2008). Western (Larus occidentalis) and Glaucous-winged gulls (L. glaucescens) nest along the Oregon coastline in a wide range of habitats. During the fall postbreeding season, at least 8 other gull species migrate into Oregon estuarine and coastal waters to over-winter (Naughton et al. 2007a:14).

Migratory Seabirds (Pelagics)

Millions of marine birds breed entirely outside of the Pacific Northwest and migrate to or through Oregon waters during the non-breeding season. Of these, the most numerous are the highly pelagic procellariids: albatrosses, shearwaters, and Northern Fulmar (Fulmarus glacialis). Three species of albatrosses breed in the western Pacific and migrate to the Oregon coast in spring: the regularly sighted Black-footed (Phoebastria nigripes), rare Laysan (P. immutabilis) and truly rare Short-tailed (P. albatrus). Short-tails are still recovering from near extinction in the 1920s due to commercial over-exploitation (USFWS 2017), but were historically as abundant as the other two albatross species (Guy et al. 2013). While the suggestion has been made that the 
distribution of the Short-tailed Albatross was once closer to shore based on their relative abundance in archaeological sites (e.g., Bovy 2005; Greenspan and Wigen 1991; Miller 1940:231), this may be more a reflection of their former absolute abundance in the coastal shelf marine bird community, as current evidence indicates Short-tails concentrate primarily at the shelf break (Kuletz et al. 2014).

Sooty Shearwaters (Ardenna grisea) ${ }^{1}$ are the most abundant shearwater in the California Current System (Veit et al 1997). These birds breed in large colonies in the Southern Hemisphere, then migrate north during the austral winter to locations throughout the North Pacific, Bering and Chukchi seas (Shaffer et al. 2006). Sooty Shearwaters are the most abundant bird in recent summer surveys off the Pacific coast and second most abundant in fall over innershelf waters (between 0 and $100 \mathrm{~m}$ offshore; Adams et al. 2014:23-24). In contrast to albatrosses and shearwaters, Northern Fulmar breed in Alaska, migrating south down both sides of the North Pacific following breeding (Hatch et al. 2010).

\section{Bird Hunting and Collecting Strategies}

Ethnographic accounts in the Pacific Northwest Coast (and worldwide) include a range of bird hunting and collecting strategies (Serjeantson 2009; Suttles 1990). Yet distinguishing between various strategies (e.g., hunting vs. scavenging) in the archaeological record is challenging (Bovy et al. 2016; deFrance 2005). We organize ethnohistorical and archaeological information on bird procurement in the Pacific Northwest Coast into four strategies.

\section{Nearshore Hunting}

Oregon coast peoples had access to a variety of nearshore habitats, including estuaries, marshes, bays, tideflats, eelgrass beds, and open waters within a few kilometers of shore. All but the most

\footnotetext{
${ }^{1}$ The American Ornithological Union (AOU) recently changed the name for Sooty Shearwaters from Puffinus griseus to Ardenna grisea (Chesser et al. 2016) based on recent genetic work; most other shearwaters are also now in the genus Ardenna, rather than Puffinus (AOU 2017).
} 
offshore birds may have been hunted in the nearshore during certain times of the year (Table 1), using bow and arrow, spears, hook and line, traps or snares. Beckham (1977:70-71) described a Tillamook method for taking waterfowl in estuaries, where men waded among the flocks wearing basketry decoys over their heads. Further north, submerged and hanging nets were used to catch large numbers of waterfowl (Suttles 1990:459).

\section{Hunting on Breeding Colonies}

Breeding colonies of seabirds may provide a relatively predictable and plentiful source of fledgling birds and eggs, and sustainable egg collection is still a staple of indigenous diets in coastal Alaska (Moss 2007; Moss and Bowers 2007; Zador et al. 2006). Adult birds may also be more vulnerable to hunting when tending their young. Ethnographic and ethnohistoric accounts discuss Native American hunting of fledgling cormorants in northern California (Gould 1966:85) and Netarts Bay (Losey 2002:81), and Barnett (1937:165) noted use of cormorant and gull eggs by several Oregon coast groups. Medullary bone and juvenile bones (indicated by porous texture and unfused epiphyses) could indicate colony exploitation for most species, although juvenile bird bones may remain unidentified or under-reported due to lack of comparative specimens or difficulties in distinguishing older juveniles (3-4 months) from adults (e.g., Bovy 2011). While many seabirds mature quickly and fledge close to adult weight (e.g., 90\% for Cassin's Auklet; Ainley et al. 1990), the Common Murre is an exception at 17-24\% (Ainley et al. 2002).

\section{Offshore Hunting}

Although some have questioned whether Oregon coast peoples ventured onto the open ocean in canoes for hunting, fishing, or birding (e.g., Lyman 1995), ethnographic research indicates ocean-going canoes were used at least occasionally (Andrews 1962:138; Minor 2001; Ray 1938:102), and archaeological analysis supports opportunistic whale hunting (Losey and Yang 
2007; Wellman et al. 2017). The presence of pelagic seabirds in archaeological assemblages has been interpreted as evidence for offshore hunting (e.g., Greenspan and Wigen 1991; Ulrich 2009). North Pacific procellariids are attracted to modern fishing vessels (Edwards et al. 2015) and may have tracked offshore fishers and marine mammal hunters in the past, perhaps through chumming (DePuydt 1994). Breeding birds were available on offshore islands, such as Goat Island on the southern Oregon coast (Gard 1990).

\section{Collecting Beached Carcasses}

Researchers in coastal regions worldwide have recognized that beached birds could be a source of bones or feathers for tool/ornament production (see references in Bovy et al. 2016). The relative abundance of remains and/or skeletal part frequency (e.g., an abundance of wing bones) has been used to argue either for or against beach scavenging (e.g., Bovy 2002; deFrance 2005; Eda et al. 2016; Jerardino et al. 2009; Losey 2002), however, Bovy et al. (2016) found these approaches of limited utility. While any aquatic bird may end up on the beach, some occur more frequently than others (Table 1); therefore relative taxonomic abundance may indicate a scavenged assemblage. Larger numbers of beached carcasses may be available during mass mortality events or "wrecks," when birds are deposited on the beach after large storms or following reproductive failure or food shortages (Bovy et al. 2016; deFrance 2005). Many of these "wreck" carcasses are relatively fresh and intact and could be used for meat (e.g., Work and Rameyer 1999). On the Oregon coast, pelagic birds are often assumed to have been collected off the beach (Hall 2001; Losey 2002:289).

\section{MATERIALS AND METHODS}

New Primary Data 
Original, unpublished identifications by the authors are drawn from collection-based projects from three sites excavated prior to 1986: Umpqua/Eden (Bovy 2005), Whale Cove (Watson 2011), and the Dunes Site (Ulrich 2009). At Umpqua/Eden and Whale Cove, 1/4" screens were used to recover the faunal remains, undoubtedly resulting in the loss of small bird bones. From the Dunes Site, we have no information as to whether screens were used. Bird remains were identified to the lowest possible taxonomic level using comparative collections from the Burke Museum of Natural History and Culture at the University of Washington (Umpqua/Eden, Whale Cove), Museum of Comparative Zoology at Harvard (Whale Cove), and the North Pacific collection at the University of Oregon's Department of Anthropology (Dunes), along with published criteria (e.g., Broughton 2004; Woolfendon 1961). Vertebrae and ribs were not identified beyond the class level (for all analysts), and Ulrich did not identify phalanges (except phalanx I of digit II). Bovy used both morphological and metric criteria to identify taxa, and did not identify small passerines. All assemblages were quantified using NISP (Number of Identified Specimens), which is primary data (not secondary, derived data like Minimum Number of Individuals; Grayson 1984; Reitz and Wing 2008), and allows comparison with other assemblages (see below).

Site 1: Umpqua/Eden

Umpqua/Eden (35DO83) is situated on the south/central Oregon coast within the territory of the Penutian-speaking Lower Umpqua or Kalawatset (Lyman 1991). The site is located on a high terrace along the Umpqua River, about $3.2 \mathrm{~km}$ from the river mouth. Excavations began with Peter Stenhouse (unpublished), were continued by Richard Ross with an Oregon State University (OSU) field school from 1978 to 1980 (Ross and Snyder 1979, 1986), and later by Rick Minor (1994; Minor et al. 2012). Lyman (1991) summarized and analyzed mammal remains from the 
Ross excavations, while Bovy analyzed the bird remains in her dissertation (2005), which focused on the effects of environmental change and human hunting on past waterbird populations. Ross and Snyder (1986) believed the site was continuously occupied for 3000 years, but with additional dating, Bovy (2005) found that the bulk of the deposits accumulated during two periods: 2280-1775 cal. BP and 900-250 cal BP. A 900-year long hiatus in site occupation, or at least faunal accumulation, occurred between 1800 and 900 cal BP.

Table 2 provides data on the 1553 bird bones from Umpqua/Eden. Ducks dominate the assemblage $(n=1120 ; 72 \%)$, followed by cormorants $(n=94 ; 6 \%)$, loons $(n=86 ; 6 \%)$, geese $(n=74$; $5 \%)$, eagles/hawks $(n=44 ; 3 \%)$ and gulls $(n=44 ; 3 \%)^{2}$. Waterfowl are the most abundant taxon in both the early and later components. Eelgrass occurs in coves both north and south of Umpqua/Eden (Gaumer et al. 1973:26), and dense flocks of Surf (Melanitta perspicillata) and White-winged Scoters (M. fusca) have been observed near the Umpqua River during November (Briggs et al.1992:A-49). Given that the most abundant ducks recovered were scoters, pochards, and Buffleheads (Bucephala albeola), and that herring and harbor seal (Phoca vitulina) were also abundant (Minor 1994; Lyman 1991), site occupants may have been targeting these productive eelgrass patches, in addition to the estuarine tideflats. Bovy (2005) identified a wide range of bird species at Umpqua/Eden, but found little change in the taxonomic composition over the site's occupation, perhaps indicating environmental stability.

\section{Site 2: Whale Cove}

Whale Cove (35LNC60) occurs within areas encompassed by the territories of the Siletz (Salish speakers) in the north and the Yaquina (Penutian speakers) in the south (Ruby and Brown 1986). Ann Bennett Rogers (Bennett 1988) excavated the site in 1985 as part of an OSU field school. Located on a bluff near Depoe Bay in northern Oregon, the site contained three strata dated to

\footnotetext{
${ }^{2}$ This does not include 1 kittiwake bone.
} 
3010-330 BP, including dense shell midden layers (Bennett and Lyman 1991). Bovy and Watson examined the avifauna in 2011 as part of Watson's undergraduate honors project at the University of Rhode Island (Watson 2011), in order to help evaluate the seasonality of the site. Most identified bird bones derive from Whale Cove I (WCI), a component dating ca. 3010-2830 BP (Bennett and Lyman 1991:244).

The Whale Cove bird assemblage is small (NISP=106) but diverse (Table 2). The most abundant taxa were ducks and geese $(n=46 ; 43 \%)$, albatrosses and shearwaters $(n=21 ; 20 \%)$, puffins and Common Murres $(\mathrm{n}=15 ; 14 \%)$, gulls $(\mathrm{n}=12 ; 11 \%)$ and cormorants $(\mathrm{n}=8 ; 7 \%)$. Watson (2011) suggested that the bird bones indicate year-round rather than seasonal occupation based on the presence of albatross and puffin (thought to be present in summer only), scoter and Northern Fulmar (fall and winter), and a juvenile cormorant (spring).

Site 3: The Dunes Site

The Dunes Site (35CLT27) is located in the Clatsop Plains dunes system, which extends $30 \mathrm{~km}$ south from the mouth of the Columbia River to Tillamook Head. It is positioned $1.2 \mathrm{~km}$ from the current shoreline, 500 meters east of Neacoxie Creek just north of the town of Gearhart, and at 15-20 m above sea level (Harrison and Longo 1991). The Lower Chinook occupied both banks of the Columbia River from the mouth to about 50 miles upstream (Ray 1938; Silverstein 1990). The Lower Chinook included the Chinook proper who occupied the north bank (to Willapa Bay) and the Clatsop who occupied the south bank (to Tillamook Head), including the Dunes Site location. The Dunes Site was occupied ca. 950-550 cal BP, and was excavated by Fred Hasle and field school students from Clatsop Community College from 1972 to 1974 (Harrison and Longo 1991). Faunal remains are housed at the University of Oregon's Museum of Natural and Cultural History. The large assemblage of bird bones was unexamined for 30 years, until Moss and 
students began to tackle the project (Rose et al. 2006). Ulrich selected the site for her M.S. project, under the direction of Moss, to investigate bird use, site seasonality, and the dynamic nature of the coastal environment near the site, including the westward progradation of extensive dunes south of the Columbia River (Connolly 1992).

Ulrich's analysis yielded 2230 NISP (Table 2); as of this writing, this represents the largest archaeological bird assemblage (from a single site) from the Oregon coast yet identified. Birds from 14 families were identified, with Common Murre $(n=594 ; 27 \%)$, scoters $(n=464$; $21 \%)$, and shearwaters $(n=453 ; 20 \%)$ dominating the assemblage. Next in abundance were other ducks and geese $(n=129,6 \%)$, Cassin's Auklets $(n=128,6 \%)$, albatrosses $(n=71,3 \%)$ loons $(n=60,3 \%)$, and gulls $(n=57,3 \%)$. Also identified are other small alcids, cormorants, Northern Fulmar, and Black-legged Kittiwake (Rissa tridactyla). Through analysis of the taxonomic composition and consideration of the habitat requirements of the most common birds, Ulrich (2009) inferred that the Dunes Site was used during multiple seasons, was located on or very near the shoreline when occupied, and its residents made use of both outer coast and nearshore environments. Ulrich (2009) suggested that the high numbers of scoters, relative to other ducks, indicated outer coastal as opposed to estuarine use.

\section{Comparative Bird Data}

Bovy and Watson compiled data from 23 additional bird assemblages on the Oregon coast

(Figure 1, Table 3). It was not possible to obtain excavated volumes and screen size information for each assemblage, so high NISP values may indicate sampling intensity, rather than the relative abundance of birds at a given site. Challenges with comparing published zooarchaeological data include differing recovery methods (screen size), availability of comparative collections, and analysts' experience and protocols (Atici et al. 2013; Driver 2011). 
Since we focus inter-site comparisons on family-level identifications (Table 4), we are confident the trends discussed adequately represent human bird use in the past.

\section{Statistical Analyses}

Moss and White used various techniques to explore structure in the bird assemblage data. Because taxonomic richness (number of taxa) is a function of sample size, which varied greatly among our sites, we used the reciprocal of the Simpson Index (Krebs 1989) to measure taxonomic diversity, which focuses instead on the equitability of abundance across taxa. To minimize sample size bias, similarity/dissimilarity matrices were created to explore assemblage relatedness across sites. Pearson product-moment correlations were computed for each pair of sites to assess inter-site comparisons using BIOMstat 3.3 (Rohlf and Slice 1999). We used cluster analysis to assess relationships among individual assemblages using arithmetic averages in the unweighted pair group method (UPGMA; Sneath and Sokal 1973:230-4) and visualized these results with dendrograms produced in Exeter Software NTSYSpc 2.11x. This technique removes size bias and allows multiple assemblages to be compared simultaneously.

We used Mantel tests to examine whether similarities between the assemblages could be related to: 1) distance between sites, 2) similarity in habitat, or 3) sample size. Mantel tests are non-parametric tests that use repeated randomizations $(n=5,000)$ to examine whether an observed pattern of pairwise relationships in an observed similarity matrix is significantly higher or lower than expected by chance when compared to a specific hypothesis test matrix (Sokal and Rohlf 2012:852-8; for archaeological application, see O'Connor et al. 2016). We calculated two matrices to describe the observed pattern of similarity among the sites. In the first, similarity was based on the presence or absence of each family at each possible pair of sites. The second used the Pearson product-moment correlation between the abundance of each family for each possible 
pair of sites. Both matrices were tested against two different hypothesis test matrices. The first tested the hypothesis that sites that are close together are more similar than those that are far apart, and was based on geographical distances between each pair of sites calculated using Google Earth. The second tested the hypothesis that sites from the same habitat type are more similar than ones belonging to different habitat types. To avoid the circular reasoning of using the bird assemblage to infer habitat type, we used three generic habitat categories: riverine/estuarine, intermediate, and outer coast. The intermediate type includes faunal assemblages from sites whose habitat may have been significantly different in the past than today (e.g., Connolly 1992; Ulrich 2009).

To investigate the relationship between modern seabird colonies and the taxonomic abundances of archaeological assemblages, we used data from the Catalog of Oregon Seabird Colonies (Naughton et al. 2007a). The most recent, accurate, or representative (MRA) estimate for each species was used (Naughton et al. 2007a:15). Moss compiled a matrix, by species, of all extant seabird colonies with a minimum of 100 birds located within 10 and $20 \mathrm{~km}$ straight line distance, respectively of the archaeological sites using georeferenced positions listed in Naughton et al. (2007a) and Google Earth (see Supplemental Table 1).

\section{COASST Analysis}

To explore the degree to which the archaeological assemblage composition could have resulted from scavenging, Parrish and Jones used the COASST dataset to calculate a modern day "baseline" composition of beached birds. Species counts were extracted for all COASST surveys (2001-2017) performed on beaches within a $20 \mathrm{~km}$ radius of each archaeological site (Figure 1; excluding a mass mortality event of Cassin's Auklets from November 2014 to February 2015). 
Carcasses were placed in taxonomic categories according to Table 5 to match the taxonomic resolution possible from archaeological findings. Note that this analysis included individual species in some families, notably the Alcidae, whereas other groups were coalesced at higher taxonomic levels, up to family (e.g., Laridae). A higher level assemblage was also produced (waterfowl, gulls, grebes, loons, alcids, procellariiformes and cormorants). In the latter case, species found in the COASST dataset but unrecorded in the archaeological datasets were included (e.g., Horned Puffins were included in Alcidae). Finally, "other species" including all non-aquatic species were excluded from the analysis, such that an "other versus other" catch-all datapoint was not included in either analysis.

For both COASST and archaeological datasets, data were standardized as percent of total within site and square-root transformed to down-weight the importance of higher values. We also created a regional COASST dataset by summing species-specific counts across all sites included in the local analysis ( $\mathrm{N}=87$ sites). The percent composition of seabird taxa assessed as NISP was regressed against the percent composition of the corresponding seabird taxa from the COASST dataset, and used general linear models (GLMs) with normally distributed errors to identify whether correlations were statistically significant, reported at a threshold of $\alpha=0.05$.

\section{RESULTS}

Native Americans living on the Oregon coast during the late Holocene used a great variety of birds (Table 4). Over 80 bird species representing 27 families have been identified from these 26 sites. The five most common taxa were Anatidae (ducks, geese) with 43\%; Alcidae (murres, puffins, auklets), 17\%; Procellariidae (fulmars, shearwaters, albatrosses), 11\%;

Phalacrocoracidae (cormorants), 9\%; and Laridae (gulls), 5\%. Ducks are the most common group at more than half the sites. We focused on sites $(n=15)$ with a minimum of 100 NISP 
(Table 5) to reduce the effects of small sample size. The results are divided into four main groups

(Figure 1), based on cluster analysis (Figure 2), taxonomic abundance (Table 5), Pearson correlation coefficients (Table 6), and taxonomic diversity (Table 7).

\section{Taxonomic and Spatial Variability}

Cluster 1: Anatids (Indian Point, Palmrose, Tahkenitch, Umpqua/Eden, Hauser, Nah-so-mah)

Six sites spanning two geographic groupings to the extreme north (Indian Point, Palmrose) and south (Tahkenitch, Umpqua/Eden, Hauser, Nah-so-mah) of our sampling region were principally defined by a predominance of anatids (57-77\%). These sites also comprised the most structured cluster, displaying pairwise correlation coefficients above 0.9 , and were relatively low in taxonomic diversity (<3.0). Assemblages at all sites with the exception of Boiler Bay, Lily Lake, and North Yaquina Head contained at least 20\% anatids. Of anatids identified beyond family, $88 \%$ were ducks, with $10 \%$ geese and $2 \%$ swans. Approximately $70 \%$ of the duck bones were identified at least to the tribe level. Of these, diving sea ducks (Mergini) dominated most assemblages (70-100\% of ducks), except for Indian Point and Nah-so-mah, where dabblers were most common (77\%, 69\%, respectively). Scoters (Melanitta spp.) were the most abundant sea duck identified at all sites ( $93 \%$ of $n=1823$ Mergini identified to species). Bufflehead was the second most abundant sea duck (5\%), followed by mergansers (Mergus spp.; 1\%).

Cluster 2: Albatrosses (Netarts, Whale Cove, Yaquina Head)

Netarts, Whale Cove, and Yaquina Head, all located on the north-central coast, have the largest percentages of albatross (12-14\%) and are characterized by the highest taxonomic diversity (>3.9). Albatrosses occur at lower percentages $(<1-4 \%)$ at a number of other sites. Netarts and Whale Cove share further similarities, with a correlation coefficient of 0.94 , including abundant anatids (25-43\%), and similar proportions of alcids (14-17\%), gulls (10-11\%), 
fulmars/shearwaters (6-8\%), and cormorants (7-8\%). While Yaquina Head has similar frequencies of some taxa, including anatids $(22 \%)$ and alcids $(12 \%)$, the assemblage is distinguished by having higher proportions of fulmars/shearwaters (27\%), and is therefore distantly grouped with cluster 3 (Figure 2).

Cluster 3: Murres and Shearwaters (Dunes, Par-Tee, Avenue Q)

Dunes, Par-Tee, and Avenue Q, all located in the extreme northern coast, have relatively high taxonomic diversity (3.0-3.9), including substantial proportions of alcids (24-52\%) and shearwaters (12-20\%), in addition to anatids (20-40\%). The small proportions of gulls (4-6\%), loons (1-3\%), cormorants (1-6\%), and albatrosses (2-3\%) are also similar. Boiler Bay is similar to these three sites with high proportions of alcids $(65 \%)$ and shearwaters $(28 \%)$, but unique in having an alcid assemblage dominated by Rhinoceros Auklet, rather than Common Murre, and an overall low taxonomic diversity (note that the assemblage is small, $\mathrm{n}=119$; just above our threshold for consideration). Common Murre is the most numerous alcid at all other sites, comprising $98-100 \%$ of the identified alcids at Par-Tee and Avenue Q, and $76 \%$ at Dunes, which has more diverse alcids, including an unusually high proportion of Cassin's Auklet (16\%). The alcid assemblages are also more diverse at Netarts and Yaquina Head (cluster 2), with greater numbers of puffins (19\%, 26\% respectively) and Rhinoceros Auklet (15\%).

Shearwaters are more abundant than Northern Fulmar at all sites, except Yaquina Head. Shearwaters can be divided into two subgroups on the basis of their flying and aquatic habits (Kuroda 1954): good gliders (e.g., Ardenna creatopus) and fluttering flyers/good divers (e.g., A. grisea). These behavioral differences have resulted in osteological differences that make it possible (along with size) to identify archaeological specimens to species (Bovy 2005:329; Kuroda 1954). Of those shearwaters identified to species, $99 \%(\mathrm{n}=548)$ were Sooty Shearwaters. 
Cluster 4: Cormorants (North Yaquina Head, Lily Lake)

North Yaquina Head and Lily Lake, both located along the central coast, form a tight grouping, with a correlation coefficient of 0.94 . Both sites have unusually high percentages of cormorants (65\%, 97\% respectively); the overall diversity at these sites is low enough to place them near the bottom of the diversity index. At Lily Lake, only eight anatid specimens were found in addition to the cormorants. Both sites are located close to modern cormorant colonies. Cormorants make up 15\% of the bird assemblage at Nah-so-mah, 13\% at Yaquina Head, and between 6 and $9 \%$ at many other sites (Table 5).

\section{Habitat Comparisons}

The results of the Mantel test and Pearson product-moment correlation indicate that similarities between sites were not due to distance between sites or sample size. We also checked to see if the presence/absence of bird families was related to habitat type (Table 7). The Mantel test found no relationship between the presence/absence of bird families in the 15 archaeological assemblages to habitat type. However, habitat type did correlate with assemblage composition, yielding the matrix correlation coefficient $r=0.168$. The probability $p$ is tested against a null hypothesis of no correlation and was found to be $p=0.0170$. Results of the random permutations were that 4814 were $<Z, 1$ was $=Z$, and $185>Z$, as shown in the histogram in Figure 3 . This suggests a strong correlation between assemblage composition and habitat type. In other words, the riverine/estuarine assemblages share some characteristics, as do intermediate habitat sites, and the outer coast sites. This is also apparent in the cluster analysis discussed above.

\section{Proximity to Murre Colonies}

Proximity had no bearing on the abundance of Common Murre NISP at archaeological sites (non-parametric correlation coefficient: $r=0.02$ ); however, extant colony size was only weakly 
correlated with Common Murre NISP $(\mathrm{r}=0.40)$. While the number of murres increases with sample size (as expected), we regressed residuals to colony size (within $10 \mathrm{~km}$, then within 20 $\mathrm{km}$ ) and exact distance to colony, but no significant relationship was found. We performed a multiple regression analysis combining exact distance and colony size, but again, no significant relationship was found.

\section{Comparisons to Modern Beached Bird Data}

Correlations between COASST beaching data and NISP data across the 15 sites were more likely to be significant when regionalized COASST data (assembled across all 87 Oregon COASST sites) at the species level were used. Only one archeological site, Boiler Bay, had a significant and strong correlation (local: $\mathrm{r}=0.940$; regional: $\mathrm{r}=0.953$ ) at the higher taxonomic assemblage level but not at the species level, which may be an artifact of the relatively low number of taxa $(\mathrm{N}=5)$ at this site. That is, when coalesced at higher taxonomic levels, the prevalence of "zeroes" in the archeological data corresponding to relatively high values in the COASST dataset (e.g., for Common Murres NISP $=0$ and COASST percentage $=43$ ) was masked. This effect, together with the observation that several archeological sites had a prevalence of only one species within the Alcidae (e.g., Boiler Bay: Rhinoceros Auklet; Par-Tee: Common Murre), or one species in addition to Common Murres (e.g., Hauser: Ancient Murrelet), suggests that a species- or lowest possible taxon-level approach is most appropriate.

When examined at the regional and species-specific level, six archeological sites displayed relatively strong, positive and significant correlations (Table 8, Figure 4). In general, sites with a high proportion of ducks in the archeological data had weak, insignificant correlations principally driven by the inversion of ducks (high in NISP, low in COASST) and Common Murres (low in NISP, high in COASST). The single exception was Tahkenitch, which 
also displayed a minor murre signal. Significant correlations were overwhelmingly driven by Common Murres (e.g. Dunes, Avenue Q) and secondarily by Northern Fulmars (e.g. Yaquina, Netarts).

\section{DISCUSSION AND CONCLUSIONS}

Native peoples used an impressive diversity of birds on the Oregon coast, from small species (e.g., sandpipers, auklets), to large-bodied taxa (e.g., pelicans, herons, swans); and from terrestrial birds (e.g., raptors, grouse), to taxa principally inhabiting the pelagic zone of the coastal shelf and slope (e.g., albatrosses, Northern Fulmar). While scoters, Common Murre, and Sooty Shearwater were the most frequently identified taxa overall, the 26 assemblages included in our study vary widely in the number and relative abundance of taxonomic groups.

While bird assemblages from sites within the same habitat category-estuarine, outer coast or intermediate - tended to share some characteristics, we found more site-specificity than expected, with subtle differences between and among habitat categories. These differences may reflect habitat change since the time the site was occupied, or site-specific patterns independent of habitat type (e.g., seasonality, selectivity), and underscore the need for caution when using taxonomic composition of bird assemblages alone to infer specific habitat types in the past.

Although determining where and how past peoples obtained birds requires careful examination of the context and taphonomy of a given assemblage (e.g., Bovy et al. 2016), our comparative analyses across many sites allows an evaluation of the potential for different procurement strategies within and among sites. In short, we see considerable variability, reflective of flexible and opportunistic use of birds.

Nearshore Hunting 
Five of the assemblages dominated by ducks (Cluster 1: Indian Point, Palmrose, Umpqua/Eden, Hauser, Nah-so-mah) are distinctly different from the COASST dataset. Ducks, especially dabbling ducks, are not commonly found as beached carcasses on the Oregon coast today. All of these sites (except possibly Palmrose) were located in riverine/estuarine environments, where ducks would be plentiful and could be hunted with relative ease. A variety of other nearshore birds may have been hunted, though some (gulls, cormorants) are also common beached birds. Many seabirds, including scoters and murres, may be more vulnerable to a range of nearshore threats, including human hunting during their flightless molt period in fall (Jones et al. 2017).

\section{Hunting on Breeding Colonies}

Despite the abundance of breeding seabirds on the Oregon coast (Naughton et al. 2007a), there is little direct evidence that people took birds from the colonies. Contemporary seabird colonies are situated on steep islets and headland cliffs making them inaccessible to terrestrial predators, including humans. There is, however, some indication of colony-based hunting at Lily Lake and North Yaquina Head (Cluster 2). Both sites have low taxonomic diversity, are dominated by cormorants, and both are close to modern seabird colonies (Supplemental Table 1). Minor et al. (2008b) found that $75 \%$ of the cormorant specimens recovered from Lily Lake were juveniles, as were many of the unidentified bird remains, supporting the interpretation that site occupants were targeting nearby colonies. Close proximity to a productive, accessible source of young birds may have eliminated the need for site occupants to hunt or scavenge birds elsewhere. Although no information was provided about the age of specimens at North Yaquina Head (Minor 1989), the similarity in species composition suggests inhabitants of this site may also have harvested juvenile birds. Small numbers of juvenile cormorants were also recovered at Netarts (Losey 2002:288) and Whale Cove (Watson 2011:5), and evidence for hunting of 
fledgling cormorants has been found in other parts of the Pacific Northwest Coast (Bovy 2007; Broughton 2004; Gould 1966). The juvenile cormorants in the Oregon coast sites are only identified to genus level.

Common Murres are the most abundant breeding bird along the Oregon coast and the most common alcid recovered from archaeological sites. There does not appear to be a relationship between murre abundance in archaeological sites and the proximity or size of current Common Murre colonies, although the breeding distribution of this species may have been different in the past. Marked population shifts at Common Murre colonies have occurred along the Washington and Oregon coasts in recent decades due to increased Bald Eagle (Haliaeetus leucocephalus) predation and shifts in prey due to changing oceanic conditions (Gladics et al. 2015; Thomas and Lyons 2017).

\section{Offshore Hunting}

The presence of pelagic taxa, such as albatrosses, Northern Fulmar and shearwaters at many Oregon coast sites raises the possibility of open ocean hunting, as these species actively avoid the immediate nearshore environment defined as the wave zone out to five kilometers (Parrish et al. 1998; Hyrenbach et al. 2002). The abundance of shearwater bones in the Dunes assemblage led Ulrich (2009) to infer that at least some were hunted in offshore waters. Yet offshore hunting is difficult to distinguish from beach scavenging (Bovy et al. 2016). Comparative data on pelagic fish and sea mammal remains might be used to investigate this hypothesis, but such data are not available for the Dunes site and are beyond the scope of this paper.

\section{Collecting Beached Carcasses}

The comparisons between the Oregon coast archaeological data and the COASST modern beached bird surveys demonstrate the possibility that beach collecting may also have occurred at 
some sites. Netarts and Yaquina Head (Cluster 2) and Dunes, Par-Tee, and Avenue Q (Cluster 3) all have similar taxonomic composition to the COASST dataset (Figure 4, Table 8). Although these relationships are driven by Common Murres, most sites also displayed relatively high proportions of the migrant pelagic taxa (albatrosses, shearwaters and/or Northern Fulmar). Murres and fulmars are predictably common beached bird species in the fall (post-breeding mortality of murres) and winter (migration exhaustion and exposure of fulmars), respectively (Parrish et al. 2007). Both species display wrecking behavior wherein thousands of freshly dead carcasses wash ashore over a short (weeks) period of time (Parrish et al. 2007, 2017). Seabird wrecks may also explain the singular predominance of alcid species at some sites (e.g., Dunes: Cassin's Auklet; Boiler Bay: Rhinoceros Auklet; Yaquina Head: Tufted Puffin; Hauser: Ancient Murrelet; Table 5), as these birds breed largely to entirely north of Oregon, migrate south into offshore waters, and are occasionally found in mass mortality events and subsequent beaching along the Oregon coast (Parrish et al. 2017).

\section{CONCLUDING REMARKS}

This study is the first to synthesize regional data of Native American bird use along the Oregon coast, and contributes to both regional and global scholarship. We used multiple analyses, including standard taxonomic abundance, diversity and correlation measures, along with cluster and regression analysis, to better elucidate the regional patterns. We document the diverse types of birds found in archaeological sites and highlight likely procurement strategies, including nearshore hunting, hunting on colonies, and collecting beached carcasses. It is difficult to compare our findings beyond the Oregon coast, as few similar studies have been conducted, although the opportunistic and flexible use of birds has been noted for coastal foragers in other regions (e.g., deFrance 2005; Jerardino et al. 2009; Kristensen 2011). 
Our interpretations incorporated life history information for major bird taxa in the Pacific Northwest, including nesting locations, habitat preference, seasonality, and scavenging potential; these discussions should provide a useful framework for others in the region. Our synthesis of all the birds recovered from Oregon coast sites will assist researchers investigating biogeographic or conservation biology questions pertaining to species of concern, such as albatrosses (Naughton et al. 2007b). Additional study of Oregon coast bird assemblages, including more detailed taphonomic studies, has enormous potential to address a variety of lingering questions, such as the role of birds within coastal subsistence strategies and the ocean-going capacities of Native American groups. Finer temporal resolution may enable us to better understand the effects of climate change on birds, such as that associated with the El Niño-Southern Oscillation. Finally, new data will help document the longer-term historical ecologies of birds, which provide essential context for understanding and addressing contemporary phenomena.

\section{ACKNOWLEDGMENTS}

We thank the Archaeology and Zoology Divisions of the Burke Museum of Natural History and Culture, the Museum of Comparative Zoology at Harvard, Oregon State University, and Ann Bennett-Rogers for access to the archaeological and comparative collections. At the University of Oregon, we acknowledge Pam Endzweig, Museum of Natural and Cultural History, for facilitating the loan of the Dunes assemblage. We thank Keith Hamm and Yu Hirasawa, two undergraduate students from Moss's 2009 Zooarchaeology course, for assisting Ulrich to analyze a portion of the collection. Many thanks are also due to the numerous archaeologists who provided site reports and other advice, including Agnes Castronuevo, Thomas Connolly, John Fagan, Ruth Greenspan, Roberta Hall, Lee Lyman, Rick Minor, Pat O’Grady, and Mark Tveskov. Bovy was partially supported through an EPA STAR (Science to Achieve Results) Fellowship 
(\#U-91576301), a NSF Dissertation Improvement Grant (\#BCS-0242632), and the Department of Anthropology at the University of Washington. COASST analyses (Parrish, Jones) were supported by NSF EHR/DRL award 1322820 and Washington Department of Fish and Wildlife award 13-1435.

\section{REFERENCES CITED}

AOU (American Ornithologists' Union). 2017. Check-list of North American Birds. Online document, http://checklist.aou.org, accessed 6/20/17.

Adams, J., J. J. Felis, J. W. Mason, and J. Y. Takekawa. 2014. Pacific Continental Shelf Environmental Assessment (PaCSEA): Aerial Seabird and Marine Mammal Surveys off Northern California, Oregon, and Washington, 2011-2012. U.S. Department of Interior, Bureau of Ocean Energy Management, Pacific OCS Region, Santa Cruz and Vallejo, CA. OCS Study BOEM 2014-003.

Aikens, C. M., T. J. Connolly, and D. L. Jenkins. 2011. Oregon Archaeology. Corvallis: Oregon State University Press.

Ainley D. G., R. J. Boekelheide, S. H. Morrell, and C. S. Strong. 1990. Chapter 10: Cassin's Auklet. In Seabirds of the Farallon Islands: Ecology, Dynamics, and Structure of an Upwelling-System Community (D. G. Ainley and R. J. Boekelheide, eds.): 306-338. Stanford: Stanford University Press.

Ainley, D. G., D. N. Nettleship, H. R. Carter and A. E. Storey. 2002. Common Murre (Uria aalge), The Birds of North America (P. G. Rodewald, ed.). Ithaca: Cornell Lab of Ornithology. Online document, https://birdsna.org/Species-Account/bna/species/commur, accessed 9/6/17. 
Andrews, R. W. 1962. Curtis' Western Indians. New York: Bonanza Books.

Atici, L., S. W. Kansa, J. Lev-Tov and E. Kansa. 2013. Other people's data: a demonstration of the imperative of publishing primary data. Journal of Archaeological Method and Theory 20(4):663-681.

Barnett, H. G. 1937. Culture element distributions VII: Oregon coat. Anthropological Records 1(3):155-204. Berkeley: University of California Publications.

Barth, J. A., B. A. Menge, J. Lubchenco, F. Chan, J. M. Bane, A. R. Kirincich, M. A. McManus, K. J. Nielsen, S. D. Pircer, and L. Washburn. 2007. Delayed upwelling alters nearshore coastal ocean ecosystems in the northern California Current. PNAS 104(10):3719-3724.

Beckham, S. D. 1977. The Indians of Western Oregon: This Land Was Theirs. Coos Bay, OR: Arago Books.

Bennett, A. C. 1988. Whale Cove (35LNC60): An Archaeological Investigation on the Central Oregon Coast. M.A. Thesis. Corvallis: Oregon State University.

Bennett, A. C. and R. L. Lyman. 1991. Archaeology of Whale Cove (35LNC60). In Prehistory of the Oregon Coast: The Effects of Excavation Strategies and Assemblage Size on Archaeological Inquiry (R. L. Lyman, ed.):241-277. San Diego: Academic Press.

Bograd, S. J., I. Schroeder, N. Sarkar, X. Qiu, W. J. Sydeman, and F. B. Schwing. 2009. Phenology of coastal upwelling in the California Current. Geophysical Research Letters 36: L01602.

Bovy, K. M. 2002. Differential avian skeletal part distribution: Explaining the abundance of wings. Journal of Archaeological Science 29:965-978. 
Bovy, K. M. 2005. Effects of Human Hunting, Climate Change and Tectonic Events on Waterbirds along the Pacific Northwest Coast during the Late Holocene. Ph.D. Dissertation. Seattle: University of Washington.

Bovy, K. M. 2007. Prehistoric human impacts on waterbirds at Watmough Bay, Washington, USA. Journal of Island and Coastal Archaeology 2:210-230.

Bovy, K. M. 2011. Archaeological evidence for a Double-Crested Cormorant (Phalacrocorax auritus) colony in the Pacific Northwest, USA. Waterbirds 34(1):89-95.

Bovy, K. M., J. E. Watson, J. Dolliver, and J. K. Parrish. 2016. Distinguishing offshore bird hunting from beach scavenging in archaeological contexts: the value of modern beach surveys. Journal of Archaeological Science 70:65-47.

Briggs, K. T., D. H. Varoujean, W. W. Williams, R. G. Ford, M. L. Bonnell, and J. L. Casey. 1992. Oregon and Washington Marine Mammal and Seabird Surveys: Final Report. Report prepared for Pacific OCS Region, Minerals Management Service, U.S. Department of the Interior. Bellevue, WA: Ebasco Environmental and Ecological Consulting, Inc.

Broughton, J. M. 2004. Prehistoric Human Impacts on California Birds: Evidence from the Emeryville Shellmound Avifauna. Ornithological Monographs No. 56. Washington, DC: American Ornithologists' Union.

Butler, V. L. and S. K. Campbell. 2004. Resource intensification and resource depression in the Pacific Northwest of North America: a zooarchaeological review. Journal of World Prehistory 18(4):327-405.

Byrne, J. V. 1962. Geomorphology of the continental terrace off the central coast of Oregon. The Ore Bin 24(5):65-74. 
COASST (Coastal Observation Seabird Survey Team). 2017. Explore data: Tables: Species list: Oregon North. Online document, http://52.86.35.235:3838/Mega_App/, accessed 9/9/17.

Chesser, R. T., K. J. Burns, C. Cicero, J. L. Dunn, A. W. Kratter, I. J. Lovette, P. C. Rasmussen, J. V. Remsen, Jr., J. D. Rising, D. F. Stotz, and K. Winker. 2016. Fifty-seventh supplement to the American Ornithologists' Union Check-list of North American Birds. The Auk 133:544560.

Colten, R. H. 2002. Prehistoric marine mammal hunting in context: Two western North American examples. International Journal of Osteoarchaeology 12:12-22.

Colten, R. H. 2015. Prehistoric coastal adaptations at Seaside, Oregon: Vertebrate fauna from the Palmrose and Par-Tee Sites. Journal of Island and Coastal Archaeology 10:253-276.

Connolly, T. J. 1992. Human Responses to Change in Coastal Geomorphology and Fauna on the Southern Northwest Coast: Archaeological Investigations at Seaside, Oregon. University of Oregon Anthropological Papers 45. Eugene: University of Oregon.

deFrance, S. D. 2005. Late Pleistocene marine birds from southern Peru: Distinguishing human capture from El Niño-induced windfall. Journal of Archaeological Science 32:1131-1146.

DePuydt, R. T. 1994. Cultural implications of avifaunal remains recovered from the Ozette Site. In Ozette Archaeological Project Research Reports, Volume II, Fauna (S. Samuels, ed.):197264. Department of Anthropology Reports of Investigation 66. Pullman: Washington State University.

Driver, J. C. 2011. Identification, classification and zooarchaeology. Ethnobiology Letters 2:1939.

Drucker, P. 1939. Contributions to Alsea ethnography. University of California Publications in American Archaeology and Ethnology 36:221-300. 
Eda, M., H. Koike, and H. Higuchi. 2016. Understanding prehistoric maritime adaptations in northern Japan: Indirect evidence from ancient DNA and histological observations of albatross (Aves: Diomedeidae) bones. Quaternary International 419:159-164.

Edwards, A. E., S. Fitzgerald, J. K. Parrish, J. Klavitter, and M. Romano. 2015. Foraging strategies of Laysan albatross inferred from stable isotopes: Implication for association with fisheries. PLoS ONE 10:e0133471.

Gard, H. A. 1990. The Role of Southern Oregon's Coastal Islands in Prehistoric Subsistence. M.A. Thesis. Corvallis: Oregon State University.

Gaston, A. J. and S. B. Dechesne. 1996. Rhinoceros Auklet (Cerorhinca monocerata). In The Birds of North America Online (A. Poole, ed.). Ithaca, New York: Cornell Lab of Ornithology.

Gaumer, T., D. Demory, and L. Osis. 1973. 1971 Coos Bay Resource Use Study. Salem: Fish Commission of Oregon.

Gladics, A. J., R. M. Suryan, J. K. Parrish, C. A. Horton, E. A. Daly, and W. T. Peterson. 2015. Environmental drivers and reproductive consequences of variation in the diet of a marine predator. Journal of Marine Systems 146 SI:72-81.

Gould, R. A. 1966. Archaeology of the Point St. George Site and Tolowa Prehistory. Berkeley: University of California Publications in Anthropology.

Grayson, D. K. 1984. Quantitative Zooarchaeology. New York: Academic Press.

Greenspan, R. L. and R. J. Wigen. 1991. Chapter 5: Vertebrate Faunal Remains. In Yaquina Head: A Middle Archaic Settlement on the North-Central Oregon Coast (R. Minor, ed.): 83120. Report No. 100. Eugene, OR: Heritage Research Associates. 
Guy, T. J., S. L. Jennings, R. M. Suryan, E. F. Melvin, M. A. Bellman, L. T. Ballance, B. A. Blackie, D. A. Croll, T. Deguchi, T. O. Geernaert, R. W. Henry, M. Hester, K. D. Hyrenbach, J. Jahncke, M. A. Kappes, K. Ozaki, J. Roletto, F. Sato, W. J. Sydeman, and J. E. Zamon. 2013. Overlap of North Pacific albatrosses with the U.S. west coast groundfish and shrimp fisheries. Fisheries Research 147:222-234.

Hall, R. L. 2001. Nah-so-mah Village, Viewed Through its Fauna. Report on file, Department of Anthropology. Corvallis: Oregon State University.

Harrison, B. F. and K. S. Longo. 1991. Archaeology at the Dunes Site (35CLT18): A Prehistoric Clatsop Village. Report on file. Astoria, OR: Clatsop Community College.

Hatch, S. A., V. A. Gill, and D. M. Mulcahy. 2010. Individual and colony-specific wintering areas of Pacific northern fulmars (Fulmarus glacialis). Canadian Journal of Fisheries and Aquatic Sciences 67(2):386-400.

Hatch, J. J. and D. V. Weseloh. 2014. Double-crested Cormorant (Phalacrocorax auritus). The Birds of North America (P. G. Rodewald, ed.). Ithaca: Cornell Lab of Ornithology. Online document, https://birdsna.org/Species-Account/bna/species/doccor, accessed 9/6/17.

Hyrenbach, K. D., P. Fernández, and D. J. Anderson. 2002. Oceanographic habitats of two sympatric North Pacific albatrosses during the breeding season. Marine Ecology Progress Series 233:283-301.

Jenkins D. L., L. G. Davis, T. W. Stafford, P. F. Campos, T. J. Connolly, L. S. Cummings, M. Hofreiter, B. Hockett, K. McDonough, I. Luthe, P. W. O’Grady, K. J. Reinhard, M. E. Swisher, F. White, B. Yates, R. M. Yohe II, C. Yost, and E. Willerslev. 2014. Geochronology, archaeological context, and DNA at the Paisley Caves. In Paleoamerican 
Odyssey (K. E. Graf, C. V. Ketron, and M. R. Waters, eds.):485-510. College Station: Texas A\&M University Press.

Jerardino, A., G. Dewar and R. Navarro. 2009. Opportunistic subsistence strategies among late Holocene coastal hunter-gatherers, Elands Bay, South Africa. Journal of Island and Coastal Archaeology 4:37-60.

Jones T. J., J. K. Parrish, A. E. Punt, V. L. Trainer, R. Kudela, J. Lang, M. S. Brancato, A. Odell, and B. Hickey. 2017. A mass mortality event of marine birds in the Northeast Pacific caused by Akashiwo sanguinea. Marine Ecology Progress Series (in press).

Krebs, C. J. 1989. Ecological Methodology. New York: Harper and Row.

Kristensen, T. J. 2011. Seasonal bird exploitation by recent Indian and Beothuk hunter-gatherers of Newfoundland. Canadian Journal of Archaeology 35:292-322.

Kroeber, A. L. 1939. Cultural and Natural Areas of Native North America. Berkeley: University of California.

Kuletz, K. J., M. Renner, E. A. Labunski, and G. L. Hunt, Jr. 2014. Changes in the distribution and abundance of albatrosses in the eastern Bering Sea: 1975-2010. Deep Sea Research II 109:282-292.

Kuroda, N. 1954. On the Classification and Phylogeny of the Order Tubinares, Particularly the Shearwaters (Puffinus), with Special Considerations on Their Osteology and Habitat Differentiation. Tokyo: Herald Co. Ltd.

Lindsay, L. W. Jr. 1995. Native use of resources on the Oregon coast. In People of the Coquille Estuary: Native Use of Resources on the Oregon Coast (R. Hall, ed.):191-210. Corvallis: Words \& Pictures Unlimited. 
Losey, R. J. 2002. Communities and Catastrophe: Tillamook Responses to the AD 1700

Earthquake and Tsunami, Northern Oregon Coast. Ph.D. Dissertation. Eugene: University of Oregon.

Losey, R. J. and D. Y. Yang. 2007. Opportunistic whale hunting on the southern Northwest Coast: ancient DNA, artifact, and ethnographic evidence. American Antiquity 72(4):657-676.

Lyman, R. L. 1991. Prehistory of the Oregon Coast: The Effects of Excavation Strategies and Assemblage Size on Archaeological Inquiry. San Diego: Academic Press.

Lyman, R. L. 1995. On the evolution of marine mammal hunting on the West Coast of North America. Journal of Anthropological Archaeology 14:45-77.

Manuwal, D. A. and A. C. Thoresen. 2011. Cassin's Auklet (Ptychoramphus aleuticus). The Birds of North America (P. G. Rodewald, ed.). Ithaca: Cornell Lab of Ornithology. Online document, https://birdsna.org/Species-Account/bna/species/casauk, accessed 9/6/17.

Miller, L. 1940. Observations on the Black-footed Albatross. The Condor 42(5):229-238.

Minor, R. 1989. Archaeology of the North Yaquina Head Shell Middens, Central Oregon Coast. Cultural Resource Series No. 3. Portland, OR: U.S. Department of Interior, Bureau of Land Management.

Minor, R. 1991a. Archaeological Investigations at the Ecola Point Site, Northern Oregon Coast. Report to Oregon State Parks and Recreation Department. Eugene: Oregon State Museum of Anthropology.

Minor, R. 1991b. Yaquina Head: A Middle Archaic Settlement on the North-Central Oregon Coast. Report No. 100. Eugene, OR: Heritage Research Associates.

Minor, R. 1994. National Register of Historic Places Registration Form for the Umpqua/Eden Site (35DO83). On file at the Oregon State Historic Preservation Office. 
Minor, R. 2001. Beyond stones and bones: What the people say about use of the offshore environment on the southernmost Northwest Coast. In Changing Landscapes: "Telling Our Stories" Proceedings of the Fourth Annual Coquille Cultural Preservation Conference, 2000 (J. Younker, M. A. Tveskov, and D. G. Lewis, eds.):25-41. North Bend, OR: Coquille Indian Tribe.

Minor, R. and R. L. Greenspan. 1995a. Archaeology of the Cape Creek Shell Midden, Cape Perpetua Scenic Area, Central Oregon Coast. Report to Siuslaw National Forest. Eugene: Oregon State Museum of Anthropology.

Minor, R. and R. L. Greenspan. 1995b. Archaeological Investigations for the Proposed Baldiyaka Interpretive Center, Coos County, Oregon. Report No. 176. Eugene, OR: Heritage Research Associates.

Minor, R. and R. L. Greenspan. 1998a. The Hauser Site: Archaeological Evidence of a PaleoEstuary in the Oregon Dunes, South-Central Oregon Coast. Report to Siuslaw National Forest. Eugene: Oregon State Museum of Anthropology.

Minor, R. and R. L. Greenspan 1998b. Archaeological Test at the Cape Blanco Lighthouse Shell Midden, Southern Oregon Coast. Report No. 216. Eugene, OR: Heritage Research Associates.

Minor, R., R. L. Greenspan, and D. C. Barner. 2008a. Chinookan resource exploitation in the Columbia River Estuary: the view from Indian Point. In Dunes, Headlands, Estuaries, and Rivers (G. L. Tasa and B. L. O'Neill, eds.):37-55. Occasional Papers No. 8. Eugene: Association of Oregon Archaeologists. 
Minor, R., R. L. Greenspan, and J. Boersema. 2008b. The Lily Lake Sites Revisited: Siuslaw Indian Settlements in the Dunes of the Central Oregon Coast. Report No. 329. Eugene, OR: Heritage Research Associates.

Minor, R. and K. A. Toepel. 1986. The Archaeology of the Tahkenitch Landing Site: Early Prehistoric Occupation on the Oregon Coast. Report No. 46. Eugene, OR: Heritage Research Associates.

Minor, R., K. A. Toepel, R. L. Greenspan, and D. C. Barner. 1985. Archaeological Investigations in the Cape Perpetua Scenic Area, Central Oregon Coast. Report No. 40. Eugene, OR: Heritage Research Associates.

Minor, R., D. Whereat, and R.L. Greenspan. 2012. Umpqua/Eden revisited: Notes on the archaeology and ethnohistory of a Lower Umpqua Indian village on the central Oregon coast. Journal of Northwest Anthropology 46(1):39-63.

Moss, M. L. 2007. Haida and Tlingit use of seabirds from the Forrester Islands, southeast Alaska. Journal of Ethnobiology 27:28-45.

Moss, M. L. 2011. Northwest Coast: Archaeology as Deep History. Washington, DC: SAA Press.

Moss, M. L. and P. M. Bowers. 2007. Migratory bird harvest in northwestern Alaska: a zooarchaeological analysis of Ipiutak and Thule occupations from the Deering Archaeological District. Arctic Anthropology 44:37-50.

Moss, M. L. and J. M. Erlandson. 1998. Early Holocene adaptations of the southern Northwest Coast. Journal of California and Great Basin Anthropology 20(1):13-25.

Moss, M. L. and J. M. Erlandson. 2008. Native American archaeological sites of the Oregon Coast: the historic context for the nomination to the National Register of Historic Places. In 
Dunes, Headlands, Estuaries, and Rivers: Current Archaeological Research on the Oregon

Coast (G. L. Tasa and B. L. O'Neill, eds.):1-36. Occasional Papers No. 8. Eugene:

Association of Oregon Archaeologists.

Moulton, G. E., editor. 1990. The Journals of the Lewis and Clark Expedition Vol. 6, November

2, 1805-March 22, 1806. Lincoln: University of Nebraska.

Naughton, M. B., D. S. Pitkin, R. W. Lowe, K. J. So, and C. S. Strong. 2007a. Catalog of

Oregon Seabird Colonies. Biological Technical Publication FWS/BTP-R1009-2007.

Washington, DC: U.S. Department of Interior, Fish and Wildlife Service.

Naughton, M. B, M. D. Romano, T. S. Zimmerman. 2007b. A Conservation Action Plan for Black-footed Albatross (Phoebastria nigripes) and Laysan Albatross (P. immutabilis). Ver.

1.0. Online document, https://www.fws.gov/pacific/migratorybirds/pdf/Albatross\%20Action\%20Plan\%20ver.1.0.pd f, accessed 11/4/16.

O'Connor, J. T., F. J. White, and T. L. Hunt. 2016. Fishhook variability and cultural transmission in East Polynesia. Archaeology in Oceania 52:32-44.

Ogle, T. B., R. T. Baker, M. Zehendner, and J. L. Fagan. 2005. Archaeological Recovery of Human Remains from 35CS1 1, Chief's Island, Gregory Point, Coos County, Oregon. Report No. 1496. Vancouver, WA: Archaeological Investigations Northwest, Inc.

Oregon Coastal Management Program (OCMP). 2016. Physical Setting. Online document, http://www.oregon.gov/LCD/OCMP/Pages/Ocean_Phys.aspx, accessed 9/2/16.

Parrish, J. K., N. Bond, H. Nevins, N. Mantua, R. Loeffel, W. T. Peterson, and J. T. Harvey. 2007. Exploring the link between beached birds and physical forcing in the California Current System. Marine Ecology Progress Series 352:275-288. 
Parrish, J. K., N. Lemberg, and L. South-Oryshchyn. 1998. Effects of colony location and nekton abundance on at-sea distribution of four seabird species. Fisheries Oceanography 7:126-135.

Parrish, J. K., K. Litle, J. Dolliver, J, T. Hass, H. Burgess, E. Frost, C. Wright, and T. Jones. 2017. Chapter 2: Defining the Baseline and Tracking Change in Seabird Populations: The Coastal Observation and Seabird Survey Team (COASST). In Citizen Science for Coastal and Marine Conservation (J. A. Cigliano and H. L. Ballard, eds.): in press. Routledge.

Ray, V. F. 1938. Lower Chinook Ethnographic Notes. University of Washington Publications in Anthropology 7(2):29-165.

Reitz, E. J. and E. S. Wing. 2008. Zooarchaeology (Second Edition). Cambridge Manuals in Archaeology. Cambridge: Cambridge University Press.

Rohlf, F. J. and D. E. Slice. 1999. BIOMstat, Version 3.3. Setauket, NY: Exeter Software.

Rose, C., A. Knust, H. Ulrich, and S. Morasci. 2006. A Preliminary Look at the Faunal Assemblage of the Dunes Site 35-CLT-27. A report for ANTH: 471, Zooarchaeology. Report on file. Eugene: University of Oregon.

Ross, R. E. and S. L. Snyder. 1979. Excavations at Umpqua/Eden. In Umpqua River Basin Cultural History, Phase I Research (T. C. Hogg, ed.): 92-104. Report to the Douglas County Commissioners, Roseburg. Corvallis: Oregon State University Department of Anthropology.

Ross, R. E. and S. L. Snyder. 1986. The Umpqua/Eden Site (35DO83): Exploitation of marine resources on the central Oregon coast. In Contributions to the Archaeology of Oregon, 19831986 (K. M. Ames, ed.):80-101. Occasional Papers No. 3. Salem: Association of Oregon Archaeologists.

Ruby, R. H. and J. A. Brown. 1986. A Guide to the Indian Tribes of the Pacific Northwest. Norman: University of Oklahoma. 
Savard, J-P. L., D. Bordage, and A. Reed. 2015. Surf Scoter (Melanitta perspicillata). The Birds of North America (P. G. Rodewald, ed.). Ithaca: Cornell Lab of Ornithology. Online document, https://birdsna.org/Species-Account/bna/species/sursco, accessed 9/6/17.

Serjeantson, D. 2009. Birds. Cambridge Manuals in Archaeology. New York: Cambridge University Press.

Shaffer, S. A., Y. Tremblay, H. Weimerskirch, D. Scott, D. R. Thompson, P, M. Sagar, H. Moller, G. A. Taylor, D. G. Foley, B. A. Block, and D. P. Costa. 2006. Migratory shearwaters integrate oceanic resources across the Pacific Ocean in an endless summer. PNAS 103:12799-12802.

Silverstein, M. 1990. Chinookans of the Lower Columbia. In Handbook of North American Indians, Vol. 7 (W.C. Sturtevant and W. Suttles, eds.):533-546. Washington, DC: Smithsonian.

Sneath, P. H. A. and R. R. Sokal. 1973. Numerical Taxonomy: The Principles and Practice of Numerical Classification. New York: W.H. Freeman.

Sokal, R. R. and F. J. Rohlf. 2012. Biometry: The Principles and Practice of Statistics in Biological Research (Fourth Edition). New York: W.H. Freeman.

Suttles, W. 1990. Environment. In Handbook of North American Indians, Vol. 7 (W. C. Sturtevant and W. Suttles, eds.):16-29. Washington: Smithsonian.

Tasa, G. L. and T. J. Connolly. 1995. Archaeological Evaluation of the Boiler Bay Site (35LNC45), in the Boiler Bay State Park Section of the Oregon Coast Highway (US Highway 101), Lincoln County, Oregon. Report 95-2. Eugene: Oregon State Museum of Anthropology. 
Tasa, G. L. and T. J. Connolly. 2001. Archaeological Investigations at Cook's Chasm Bridge, the Good Fortune Point Site (35LNC55), and the Neptune Site (35LA3). Report 2001-4. Eugene: Oregon State Museum of Anthropology.

Tasa, G. L., J. A. Knowles, and T. J. Connolly. 2009. Archaeological Evaluation of the Bob Creek Site (35LA10): Oregon Coast Highway (US Highway 101), Lane County. Report 2009066. Eugene: Oregon State Museum of Anthropology.

Thomas, S. M. and J. E. Lyons. 2017. Populations trends and distribution of Common Murre Uria aalge colonies in Washington 1996-2015. Marine Ornithology 45:95-102.

Thompson, L. C. and M. D. Kinkade. 1990. Languages. In Handbook of North American Indians, Vol. 7 (W. C. Sturtevant and W. Suttles, eds.): 30-51. Washington, DC: Smithsonian.

Tveskov, M. A. 2000. The Coos and Coquille: A Northwest Coast Historical Anthropology. Ph.D. Dissertation: Eugene, University of Oregon.

Tveskov, M. and A. Cohen. 2007. Ni-Les'Tun Archaeology: The Bussmann, Blue Barn, and Old Town Bandon Sites. Research Report 2007-1. Ashland: Southern Oregon University Laboratory of Anthropology.

USFWS (U.S. Fish and Wildlife Service). 2017. Oregon Fish and Wildlife Office, Short-tailed Albatross. Online documents, https://www.fws.gov/oregonfwo/articles.cfm?id=149489452, accessed July 31, 2017.

Ulrich, H.A. 2009. Analysis of Bird Remains from the Dunes Site (35-CLT-27), Northern Oregon Coast. M.S. Eugene: University of Oregon. 
Veit, R. R., J. A. McGowan, D. G. Ainley, R. R. Wahl, and P. Pyle. 1997. Apex marine predator declines ninety percent in association with changing oceanic climate. Global Change Biology $3: 23-28$.

Wallace, E. A. and G. E. Wallace. 1998. Brandt's Cormorant (Phalacrocorax penicillatus). The Birds of North America (P. G. Rodewald, ed.). Ithaca: Cornell Lab of Ornithology. Online document, https://birdsna.org/Species-Account/bna/species/bracor, accessed 9/6/17.

Watson, J. 2011. Seasonality on the Oregon Coast: Avian Faunal Remains from Whale Cove (35-LNC-60). Undergraduate Honors Paper. Kingston: University of Rhode Island.

Wellman, H. P., T. C. Rick, A. T. Rodrigues, and D. Y. Yang. 2017. Evaluating ancient whale exploitation on the northern Oregon Coast through ancient DNA and zooarchaeological analysis, Journal of Island and Coastal Archaeology 12(2):255-275.

Wiese, F. K., J. K. Parrish, C. W. Thompson, and C. Maranto. 2008. Ecosystem-based management of predator-prey relationships: Piscivorous birds and salmonids in the midColumbia River. Ecological Applications 18:681-700.

Woolfenden, G. E. 1961. Postcranial osteology of the waterfowl. Bulletin of the Florida State Museum: Biological Sciences 6:1-129.

Work, T. M. and R. A. Rameyer. 1999. Mass stranding of wedge-tailed shearwater chicks in Hawaii. Journal of Wildlife Diseases 35(3):487-495.

Zador, S. G., Piatt, J. F., and A. E. Punt. 2006. Balancing predation and egg harvest in a colonial seabird: A simulation model. Ecological Modeling 195(3-4):318-326. 
Figure Captions:

Figure 1. A. Regional map of the Pacific Northwest Coast (USA); B. Map of Oregon coast showing location of archaeological sites with identified bird bones, COASST survey beaches included in the analysis, and major Indian tribes (in capitals). Open circles indicate sites with $<100$ NISP, which were excluded from the comparative analyses. See Table 3 for site numbers.

Figure 2. Dendrogram showing results of cluster analysis.

Figure 3. Mantel test histogram, showing the strong correlation between bird assemblage composition and habitat types. The solid vertical line represents the matrix correlation $(\mathrm{r}=$ 0.16812). As shown, 4814 random permutations are positioned to the left, 1 is atop the line, and 185 occur to the right. The correlation is in the significantly high range of possible correlation values.

Figure 4. The relationship between the taxonomic composition (see Table 5) of aquatic bird carcasses washing ashore on Oregon beaches (data from the COASST program) and that of archaeological sites (see Figure 1). Data are percent composition over all carcasses (or NISP) found, square-root transformed to down-weight high values. Sites with any level of association (Pearson's R above 0.4) are bolded (site name and graph outline), and have linear fits (dashed lines). Higher associations are all driven by high proportions of murres (black circles). 

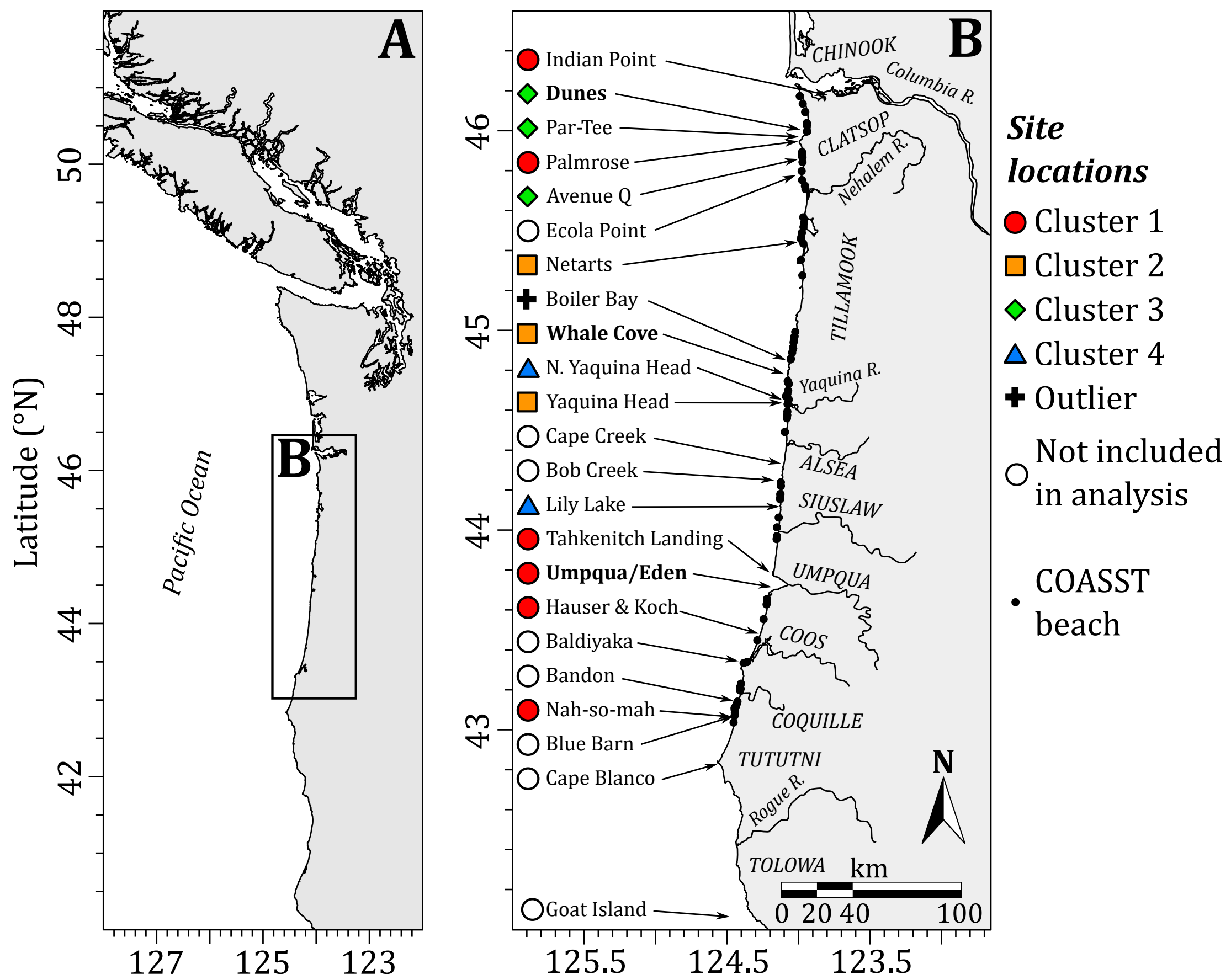


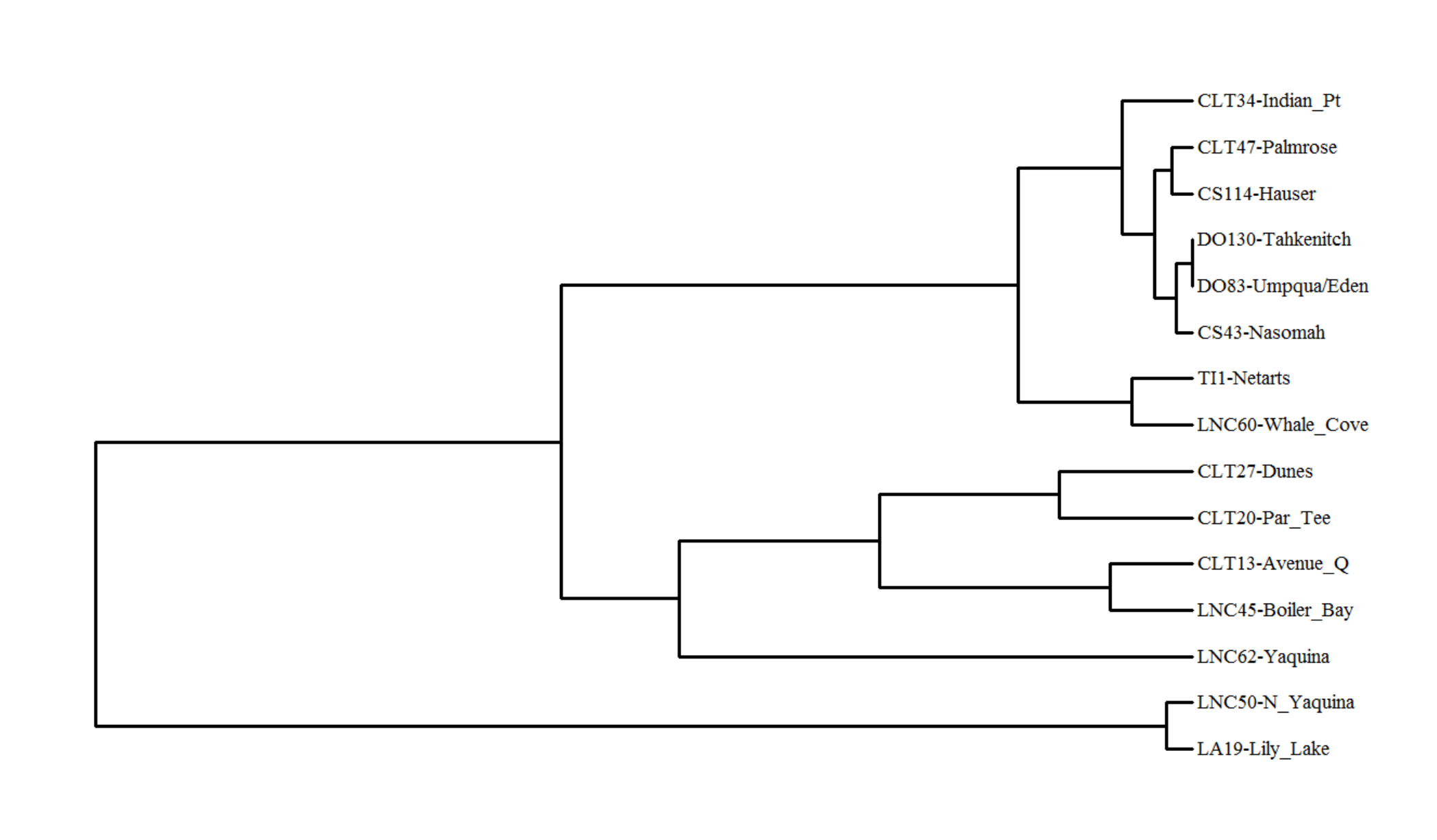




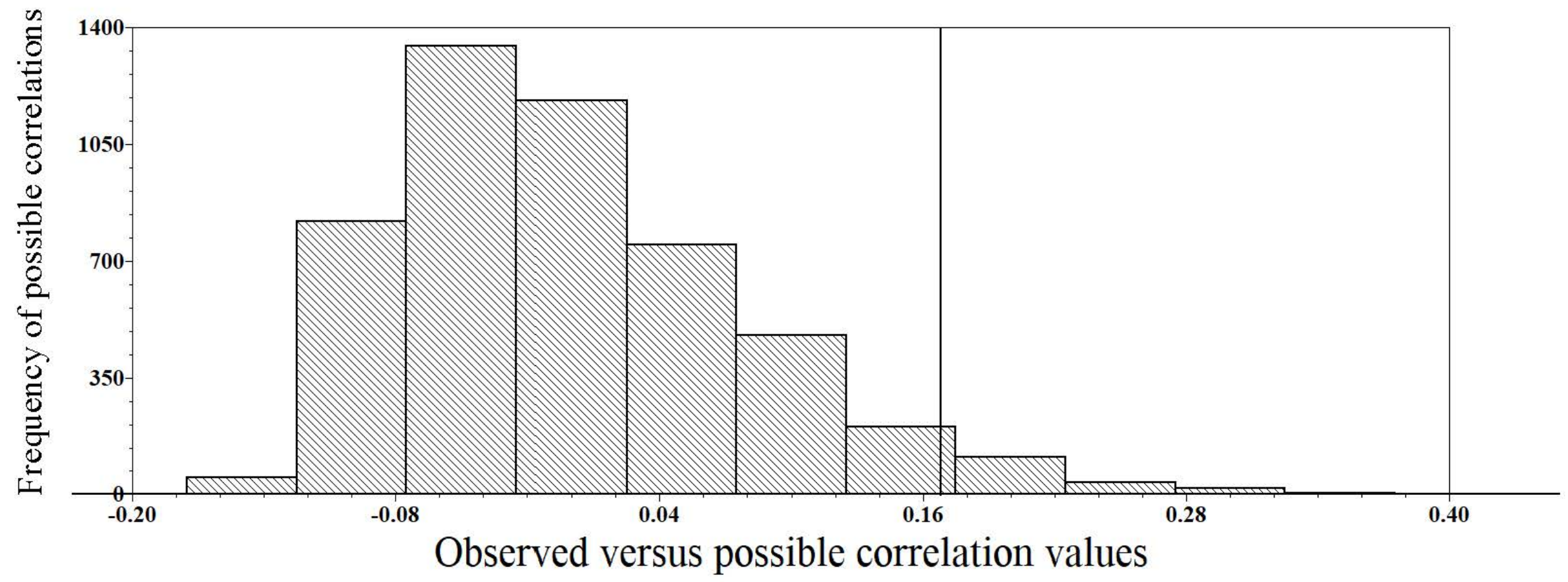



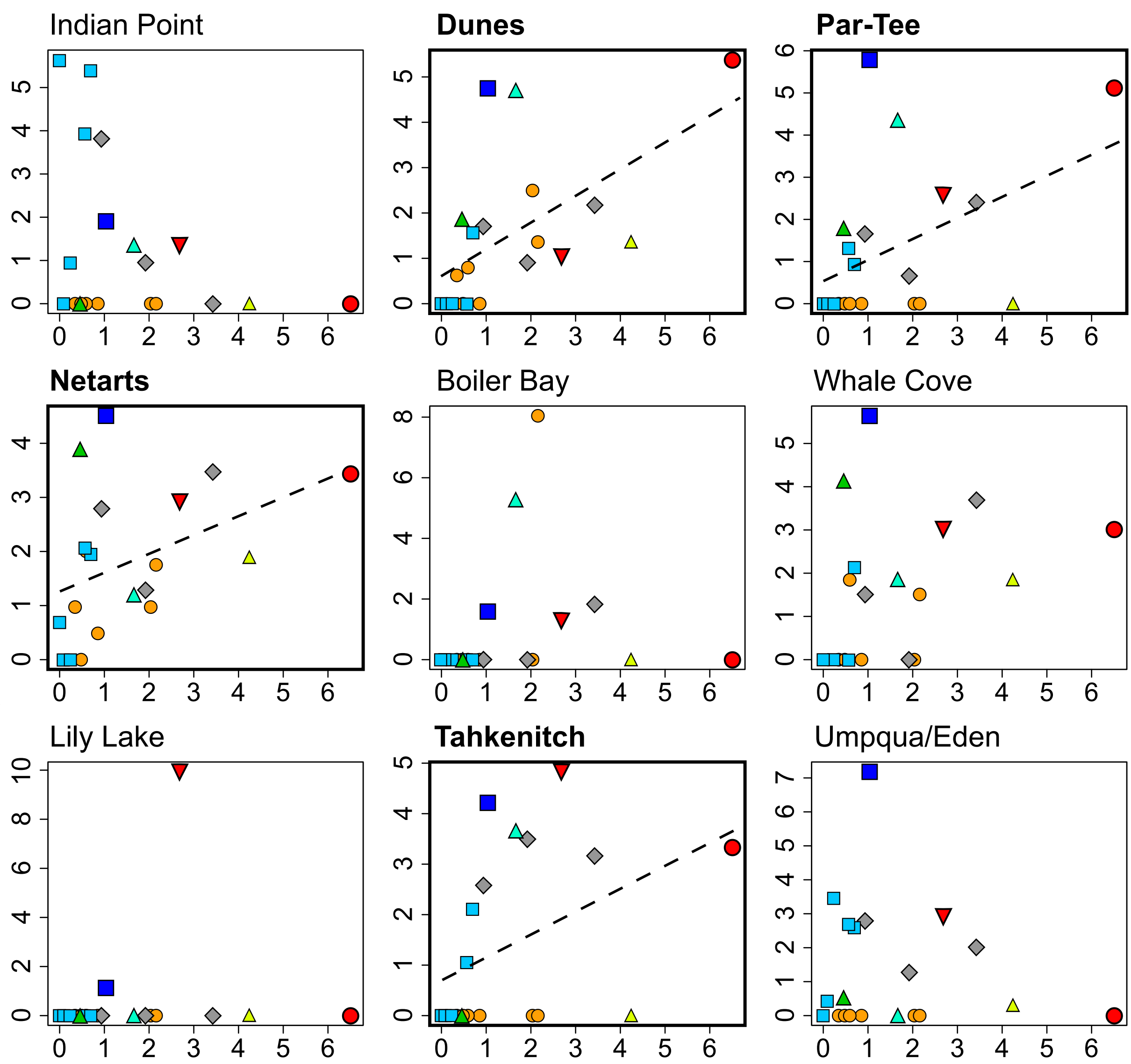

Tahkenitch
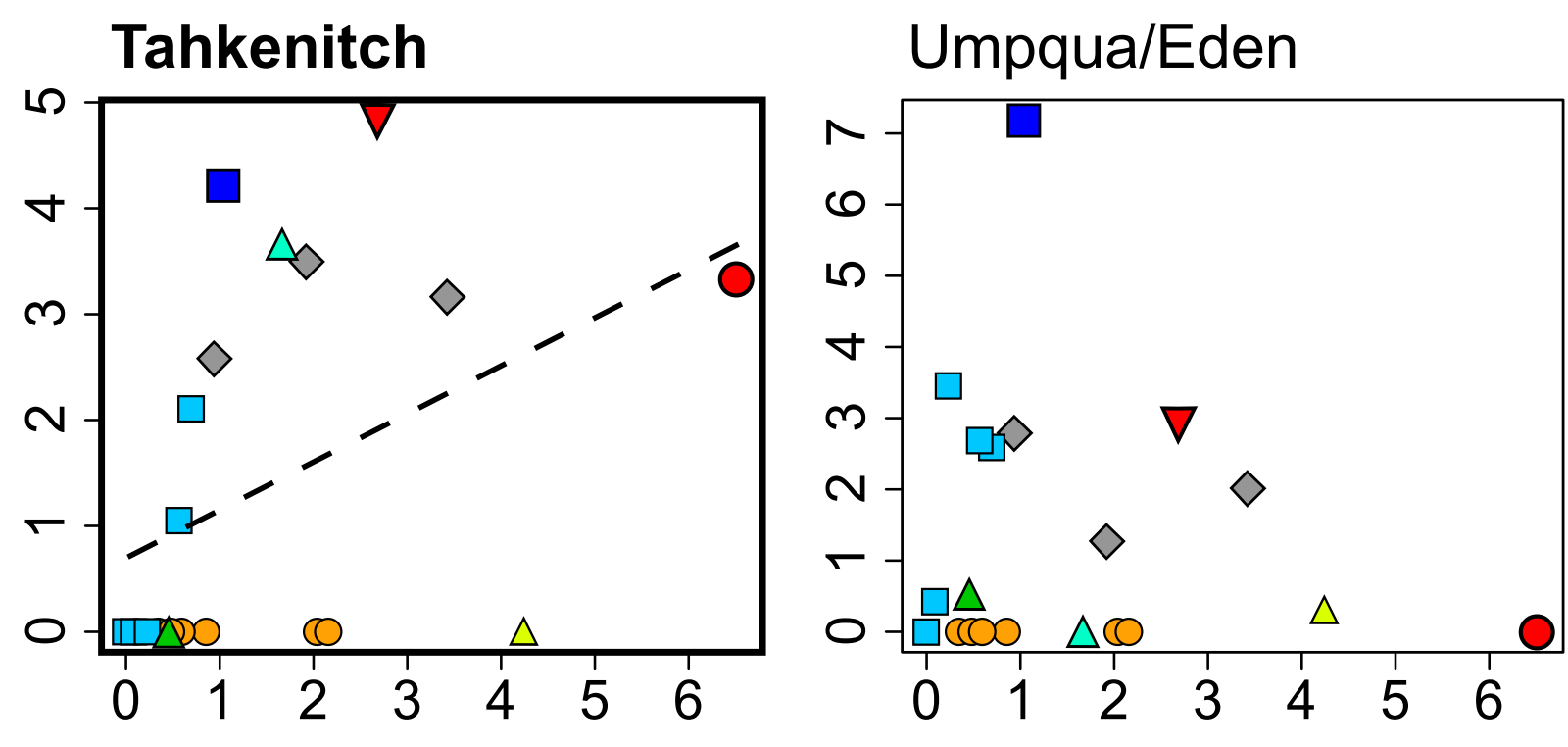

Palmrose

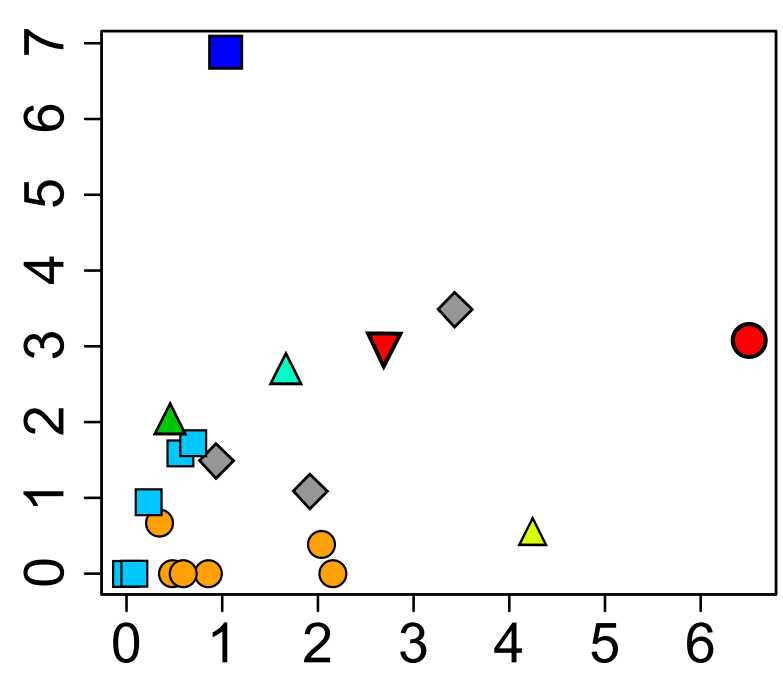

Avenue Q

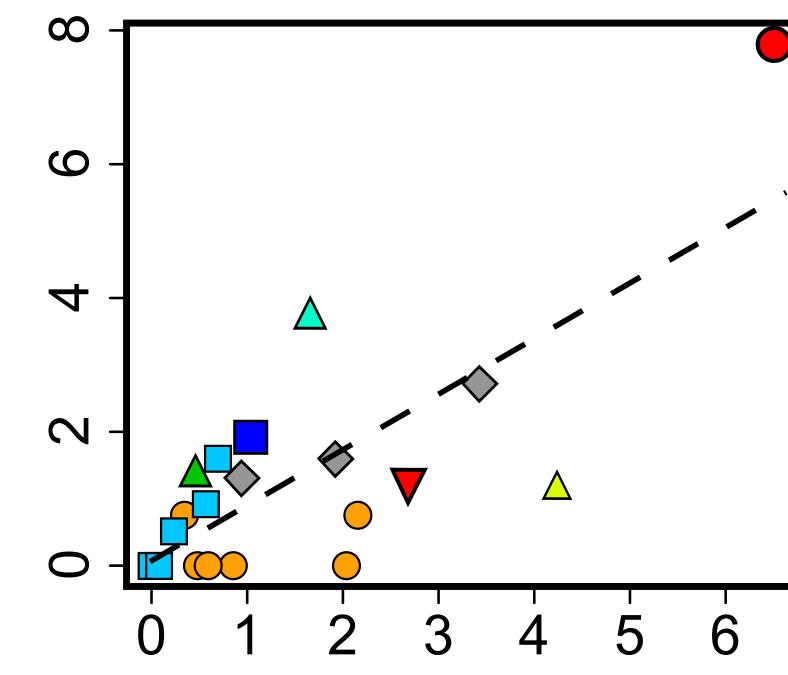

N. Yaquina

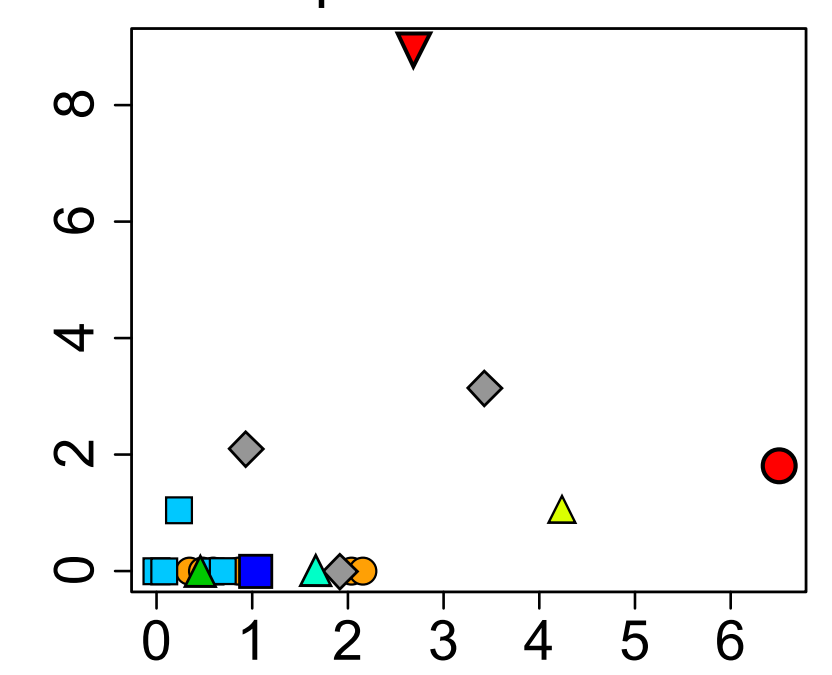

Yaquina Head

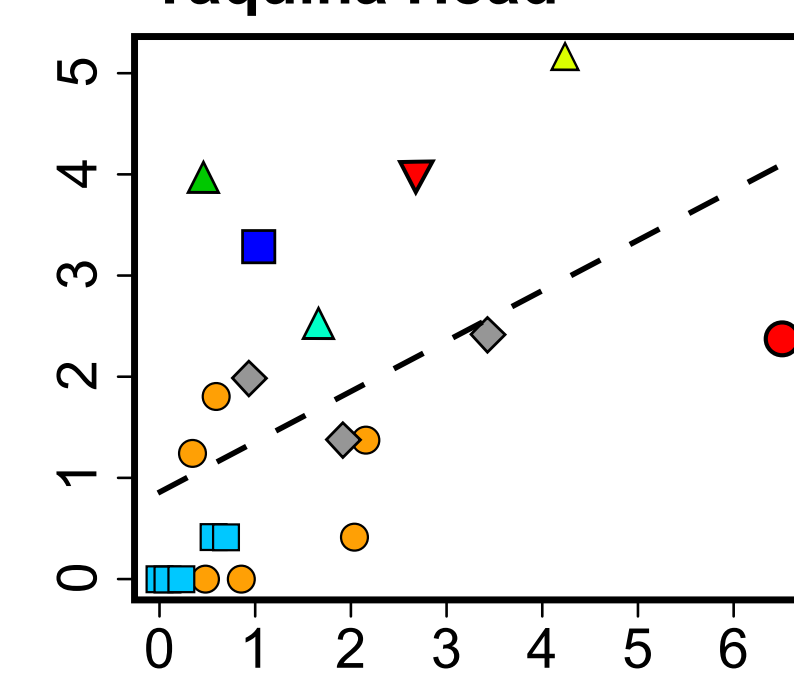

Hauser

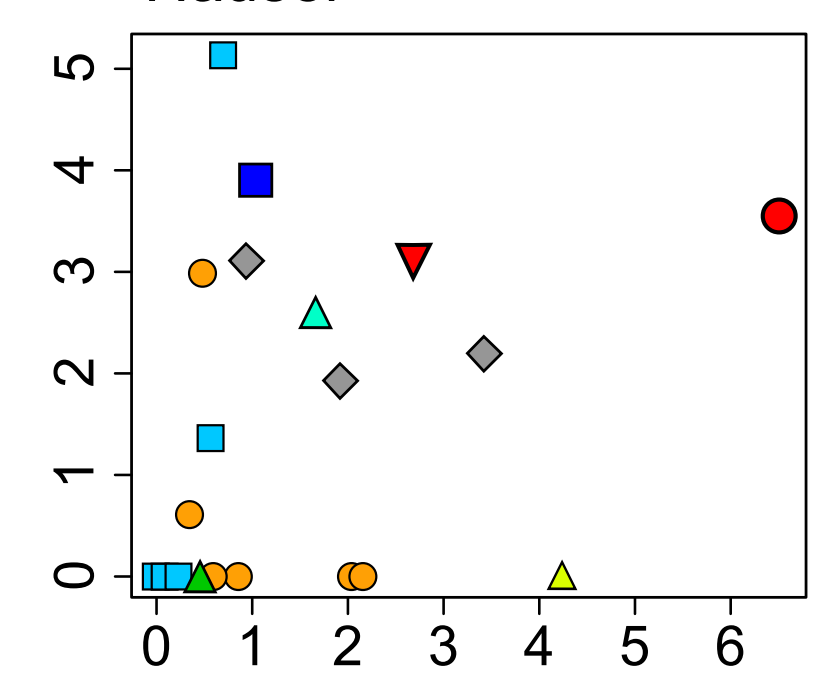

Nah-so-mah

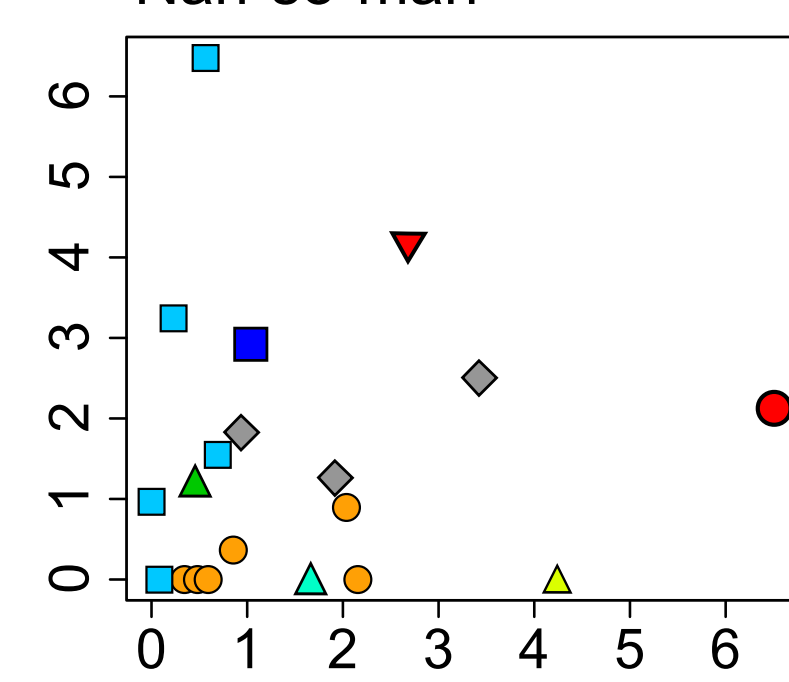

Common Murre Other Alcid
Diving Sea Ducks $\square$ Other Waterfowl $\triangle$ Albatrosses

$\triangle$ Northern Fulmar $\triangle$ Shearwaters $\nabla$ Cormorants $\diamond$ Other 
Table 1: Life history information for Oregon coast birds (discussed in the text).

\begin{tabular}{|c|c|c|c|c|c|}
\hline & Nesting Locations & Habitat Preference in Oregon & Seasonality (peak abundance) & Scavenging Potential $^{1}$ & References \\
\hline \multicolumn{6}{|c|}{ Waterfowl (Anatids) } \\
\hline $\begin{array}{l}\text { Dabbling } \\
\text { Ducks and } \\
\text { Geese }\end{array}$ & $\begin{array}{l}\text { many breed in Alaska and } \\
\text { Canada; a few breed locally }\end{array}$ & $\begin{array}{l}\text { estuaries, tidal flats, marshes, } \\
\text { lakes, fields }\end{array}$ & $\begin{array}{l}\text { winter (and spring/ fall } \\
\text { migrations); some year-round } \\
\text { (e.g., Canada Goose, Mallards) }\end{array}$ & rare beached bird & \\
\hline Scoters & breed in Alaska and Canada & estuaries and nearshore bays & $\begin{array}{l}\text { winter (and spring/ fall } \\
\text { migrations) }\end{array}$ & $\begin{array}{l}\text { uncommon beached bird }(\# 12,18) \text {; } \\
\text { wreck species }\end{array}$ & Savard et al. 2015 \\
\hline \multicolumn{6}{|c|}{ Seabirds Nesting along the Oregon Coast } \\
\hline $\begin{array}{l}\text { Common } \\
\text { Murre }\end{array}$ & $\begin{array}{l}\text { cliff nester; offshore } \\
\text { rocks/islands }\end{array}$ & nearshore and large estuaries & year-round & $\begin{array}{l}\text { common beached bird (\#1); } \\
\text { post-breeding mortality species; } \\
\text { wreck species }\end{array}$ & Ainley et al. 2002 \\
\hline $\begin{array}{l}\text { Rhinoceros } \\
\text { Auklet }\end{array}$ & $\begin{array}{l}\text { burrow nester; offshore } \\
\text { rocks/islands; population } \\
\text { center in Canada }\end{array}$ & $\begin{array}{l}\text { shelf waters to nearshore and } \\
\text { large estuaries }\end{array}$ & $\begin{array}{l}\text { year-round (farther offshore in } \\
\text { winter) }\end{array}$ & $\begin{array}{l}\text { common beached bird }(\# 5) \text {; } \\
\text { post-breeding/winterkill species; } \\
\text { wreck potential }\end{array}$ & $\begin{array}{l}\text { Gaston and Dechesne } \\
1996\end{array}$ \\
\hline $\begin{array}{l}\text { Cassin's } \\
\text { Auklet }\end{array}$ & $\begin{array}{l}\text { burrow nester; offshore } \\
\text { rocks/islands; population } \\
\text { center in Canada }\end{array}$ & shelf waters to nearshore & $\begin{array}{l}\text { year-round (farther offshore in } \\
\text { winter) }\end{array}$ & $\begin{array}{l}\text { common beached bird }(\# 3) \text {; } \\
\text { post-breeding/winterkill species; } \\
\text { wreck potential }\end{array}$ & $\begin{array}{l}\text { Manuwal and Thoresen } \\
2011\end{array}$ \\
\hline Cormorants & $\begin{array}{l}\text { surface nester; offshore } \\
\text { rocks/islands; manmade } \\
\text { structures }\end{array}$ & $\begin{array}{l}\text { nearshore, estuaries, lower } \\
\text { Columbia river; freshwater } \\
\text { bodies (Double-crested } \\
\text { Cormorants) }\end{array}$ & common year-round & $\begin{array}{l}\text { common beached bird }(\# 10,14,27) \text {; } \\
\text { post-breeding mortality species }\end{array}$ & $\begin{array}{l}\text { Wallace and Wallace } \\
\text { 1998; Hatch and } \\
\text { Weseloh } 2014\end{array}$ \\
\hline Gulls & $\begin{array}{l}\text { surface nester; offshore } \\
\text { rocks/islands; manmade } \\
\text { structures }\end{array}$ & $\begin{array}{l}\text { ubiquitous across marine and } \\
\text { freshwater settings (including all } \\
\text { species) }\end{array}$ & $\begin{array}{l}\text { common year-round (but variable } \\
\text { by species) }\end{array}$ & $\begin{array}{l}\text { common beached bird }(\# 4+) \text {; } \\
\text { post-breeding mortality species }\end{array}$ & \\
\hline \multicolumn{6}{|c|}{ Migratory Seabirds (Pelagics) } \\
\hline Albatrosses & breed in western Pacific & shelf and slope waters & summer (Apr to Oct) & uncommon-to-rare beached bird & Hyrenbach et al. 2002 \\
\hline $\begin{array}{l}\text { Sooty } \\
\text { Shearwater }\end{array}$ & $\begin{array}{l}\text { breed in New Zealand and } \\
\text { Australia }\end{array}$ & shelf and slope waters & $\begin{array}{l}\text { summer (and spring/ fall } \\
\text { migrations) }\end{array}$ & common beached bird (\#7) & Veit et al. 1997 \\
\hline $\begin{array}{l}\text { Northern } \\
\text { Fulmar }\end{array}$ & $\begin{array}{l}\text { breed in Alaska and Canadian } \\
\text { Arctic }\end{array}$ & shelf waters & winter (Sept to Feb) & $\begin{array}{l}\text { common beached bird (\#2); } \\
\text { winterkill species; } \\
\text { wreck species }\end{array}$ & Hatch et al. 2010 \\
\hline
\end{tabular}


Table 2. Identified specimens from Umpqua/ Eden (35DO83), Dunes Site (35CLT27) and Whale Cove (35LNC60).

\begin{tabular}{|c|c|c|c|c|}
\hline Scientific Name $^{1}$ & Common Name & Umpqua/Eden $^{2}$ & Whale Cove & Dunes \\
\hline \multicolumn{5}{|l|}{ Anseriformes } \\
\hline Anatidae & Duck, Goose, Swan & 4 & & 14 \\
\hline Anserinae & Goose, Swan & & & 12 \\
\hline Anserini & Goose & 49 & 4 & \\
\hline Branta cf. canadensis & Canada Goose & 25 & & \\
\hline Branta canadensis & Canada Goose & & & 39 \\
\hline Anatinae & Duck & 336 & 14 & 64 \\
\hline Anas spp. & Dabbling Duck & 80 & & \\
\hline Aythya spp. & Pochard & 132 & & \\
\hline Mergini & Sea Duck & 75 & 7 & \\
\hline Melanitta spp. & Scoter & 315 & 17 & 60 \\
\hline Melanitta perspicillata & Surf Scoter & 54 & & 200 \\
\hline Melanitta fusca & White-winged Scoter & 32 & 4 & 204 \\
\hline Bucephala albeola & Bufflehead & 81 & & \\
\hline Bucephala spp.- large & Common or Barrow's Goldeneye & 3 & & \\
\hline Bucephala islandica & Barrow's Goldeneye & 1 & & \\
\hline Mergus spp. & Merganser & 7 & & \\
\hline Mergus merganser & Common Merganser & 2 & & \\
\hline Oxyura jamaicensis & Ruddy Duck & 2 & & \\
\hline \multicolumn{5}{|l|}{ Galliformes } \\
\hline Gallus gallus & Domestic Chicken & 8 & & \\
\hline \multicolumn{5}{|l|}{ Podicipediformes } \\
\hline Podicipedidae & Grebe & 4 & & 4 \\
\hline Podiceps spp. & Grebe & & & 5 \\
\hline Podiceps spp.- small & Horned or Eared Grebe & 3 & & \\
\hline Podiceps auritus & Horned Grebe & 6 & & \\
\hline Aechmophorus spp. & Western or Clark's Grebe & 5 & & \\
\hline Aechmophorus occidentalis & Western Grebe & & & 8 \\
\hline \multicolumn{5}{|l|}{ Columbiformes } \\
\hline Columba spp. & Pigeons & & & 12 \\
\hline \multicolumn{5}{|l|}{ Gruiformes } \\
\hline Grus canadensis & Sandhill Crane & 1 & & \\
\hline Charadriiformes & Shorebird & 1 & & \\
\hline Scolopacidae & Sandpiper & 5 & & \\
\hline Calidris spp. & Sandpiper & 5 & & \\
\hline Alcidae & Alcid & 1 & 2 & 30 \\
\hline Uria a alge & Common Murre & & 8 & 594 \\
\hline Brachyramphus marmoratus & Marbled Murrelet & & & 8 \\
\hline Ptychoramphus aleuticus & Cassin's Auklet & & & 128 \\
\hline Cerorhinca monocerata & Rhinoceros Auklet & & 2 & 38 \\
\hline
\end{tabular}




\begin{tabular}{|c|c|c|c|c|}
\hline Scientific Name $^{1}$ & Common Name & Umpqua/Eden ${ }^{2}$ & Whale Cove & Dunes \\
\hline Fratercula cirrhata & Tufted Puffin & & 3 & 13 \\
\hline Laridae & Gull, Tern & 44 & 12 & 10 \\
\hline Rissa cf. tridactyla & Black-legged Kittiwake & 1 & & \\
\hline Rissa tridactyla & Black-legged Kittiwake & & & 40 \\
\hline Larus spp. & Gulls & & & 47 \\
\hline \multicolumn{5}{|l|}{ Gaviiformes } \\
\hline Gavia spp. & Loon & 59 & 2 & 60 \\
\hline Gavia stellata & Red-throated Loon & 8 & & \\
\hline Gavia pacifica & Pacific Loon & 8 & & \\
\hline Gavia immer & Common Loon & 11 & & \\
\hline \multicolumn{5}{|l|}{ Procellariiformes } \\
\hline Phoebastria spp. & Albatross & & 15 & 71 \\
\hline Phoebastria spp.- small & Laysan or Black-footed Albatross & 1 & & \\
\hline Phoebastria albatrus & Short-tailed Albatross & 2 & & \\
\hline Procellariidae & Shearwater, Fulmar, Petrel & 1 & & 17 \\
\hline Fulmarus glacialis & Northern Fulmar & 1 & 3 & 38 \\
\hline Ardenna (=Puffinus) spp. & Shearwater & & 3 & 127 \\
\hline Ardenna grisea & Sooty Shearwater & & & 324 \\
\hline Ardenna creatopus & Pink-footed Shearwater & & & 2 \\
\hline \multicolumn{5}{|l|}{ Suliformes } \\
\hline Phalacrocorax spp. & Cormorant & 54 & 3 & 22 \\
\hline Phalacrocorax penicillatus & Brandt's Cormorant & 1 & & \\
\hline Phalacrocorax auritus & Double-crested Cormorant & 28 & 1 & \\
\hline Phalacrocorax pelagicus & Pelagic Cormorant & 11 & 4 & \\
\hline \multicolumn{5}{|l|}{ Pelecaniformes } \\
\hline Pelecanus spp. & Pelican & 5 & & \\
\hline Pelecanus occidentalis & Brown Pelican & 6 & & 3 \\
\hline Ardea herodias & Great Blue Heron & 1 & & \\
\hline \multicolumn{5}{|l|}{ Accipitriformes } \\
\hline Pandion haliaetus & Osprey & 3 & & \\
\hline Accipitridae- large & Bald or Golden Eagle & 5 & & \\
\hline Haliaeetus leucocephalus & Bald Eagle & 18 & & 1 \\
\hline Accipitridae- small & Hawk & 2 & & \\
\hline Buteo spp. & Hawk & 14 & & \\
\hline Buteo jamaicensis & Red-tailed Hawk & 5 & & \\
\hline \multicolumn{5}{|l|}{ Strigiformes } \\
\hline Megascops kennicotti & Western Screech-owl & 1 & & \\
\hline Bubo spp. & Great Horned or Snowy Owl & 1 & & \\
\hline Bubo virginianus & Great Horned Owl & 1 & & 1 \\
\hline \multicolumn{5}{|l|}{ Piciformes } \\
\hline Picidae & Woodpecker & 1 & 1 & \\
\hline \multicolumn{5}{|l|}{ Falconiformes } \\
\hline Falco spp.- large & Falcon, large-sized & 1 & & \\
\hline
\end{tabular}




\begin{tabular}{|c|c|c|c|c|}
\hline Scientific Name $^{T}$ & Common Name & Umpqua/Eden ${ }^{2}$ & Whale Cove & Dunes \\
\hline \multicolumn{5}{|l|}{ Passeriformes } \\
\hline Passeriformes (non-corvid) & Perching Bird & 11 & 1 & 1 \\
\hline Turdidae & Robin, Thrush & & & 4 \\
\hline Corvus brachyrhynchos & American or Common Crow & 11 & & \\
\hline Corvus corax & Common Raven & & & 29 \\
\hline Total & & $\overline{1553}$ & 106 & 2230 \\
\hline
\end{tabular}

${ }^{1}$ Taxonomic names and order follows the American Ornithologists' Union Check-list of North American Birds (AOU 2017), including recent updates (e.g., Chesser et al. 2016).

${ }^{2}$ Simplified from Bovy (2005), which also included size class information for non-species identifications (e.g., Anas sp.- small). In addition, some identifications were combined (e.g., cf. Phalacrocorax spp. and Phalacrocorax spp.). 
Table 3. Oregon coast archaeological sites with identified bird remains (organized from north to south).

\begin{tabular}{|c|c|c|c|c|c|c|c|}
\hline Site No. & Site Name & Period $^{1}$ & Excavation (Excavator, Date) ${ }^{2}$ & Faunal Analyst & Report & $\mathbf{N S P}^{3}$ & NISP $^{3}$ \\
\hline 35CLT34 & Indian Point & $\mathrm{LH}, \mathrm{PH}$ & Minor 1978 & Wigen & Minor et al. (2008a) & 804 & 256 \\
\hline $35 \mathrm{CLT} 27$ & Dunes & $\mathrm{LH}$ & Hasle 1972-1974 & Ulrich & Ulrich (2009) & 4179 & 2230 \\
\hline 35 CLT20 & Par-Tee & $\mathrm{LH}$ & Phebus \& Drucker 1960/70s & Colten & Colten $(2002,2015)$ & 1396 & 749 \\
\hline 35CLT47 & Palmrose & $\mathrm{LH}$ & $\begin{array}{l}\text { Phebus \& Drucker 1960/70s; Connolly } \\
1988\end{array}$ & Crockford; Colten & $\begin{array}{l}\text { Connolly et al. (1992); } \\
\text { Colten }(2002,2015)\end{array}$ & 1483 & 800 \\
\hline 35CLT13 & Avenue Q & LH & Connolly 1988 & Crockford & Connolly et al. (1992) & 806 & 425 \\
\hline 35CLT21B & Ecola Point & LH, PH & Minor 1990 & Greenspan & Minor (1991a) & 132 & 77 \\
\hline $35 \mathrm{TI} 1$ & Netarts & $\mathrm{LH}$ & Newman \& Collins 1950s; Losey 1999 & Losey & Losey (2002) & 1241 & 524 \\
\hline $35 \mathrm{LNC} 45$ & Boiler Bay & $\mathrm{MH}$ & Tasa \& Connolly 1993 & Penton, Tasa & Tasa \& Connolly (1995) & 248 & 119 \\
\hline 35LNC60 & Whale Cove & LH & Bennett-Rogers \& Lyman 1985 & Watson, Bovy & Watson (2011) & 151 & 106 \\
\hline $35 \mathrm{LNC} 50$ & North Yaquina Head & $\mathrm{LH}$ & Minor 1988 & Greenspan, Wigen & Minor (1989) & 162 & 113 \\
\hline 35LNC62 & Yaquina Head & MH, LH & Minor 1989 & Wigen & Minor (1991b) & 1734 & 716 \\
\hline 35LNC57 & Cape Creek & LH & Minor 1991,1992 & Greenspan & Minor \& Greenspan (1995a) & 144 & 75 \\
\hline 35LNC55 & Good Fortune Point & $\mathrm{LH}$ & $\begin{array}{l}\text { Minor \& Toepel 1983; Connolly \& Tasa } \\
2000\end{array}$ & Greenspan; Tasa & $\begin{array}{l}\text { Minor et al. (1985); Tasa \& } \\
\text { Connolly (2001) }\end{array}$ & 32 & 3 \\
\hline 35LNC56 & Good Fortune Cove & $\mathrm{LH}$ & Minor \& Toepel 1983 & Greenspan & Minor et al. (1985) & 68 & 19 \\
\hline 35LA10 & Bob Creek & $\mathrm{LH}$ & Tasa et al. 2000s & Singer & Tasa et al. (2009) & 18 & 8 \\
\hline 35LA19 & Lily Lake & $\mathrm{PH}$ & Minor 1999 & Greenspan & Minor et al. (2008b) & 613 & 239 \\
\hline $35 \mathrm{DO} 130$ & Tahkenitch Landing & $\mathrm{MH}$ & Minor \& Toepel 1985 & Greenspan & Minor \& Toepel (1986) & 780 & 245 \\
\hline $35 \mathrm{DO} 83$ & Umpqua/Eden & LH, PH & Ross 1978-1980 & Bovy & Bovy (2005) & $\begin{array}{r}\text { not } \\
\text { reported }\end{array}$ & 1553 \\
\hline $35 \mathrm{CS} 114$ & Hauser & $\mathrm{LH}$ & Minor 1991- 1993 & Greenspan & Minor et al. (1998a) & 934 & 436 \\
\hline $35 \mathrm{CS} 119$ & Koch & $\mathrm{LH}$ & Minor 1993 & Greenspan & Minor et al. (1998a) & 324 & 95 \\
\hline $35 \mathrm{CS} 11$ & $\begin{array}{l}\text { Baldiyaka/ Chief's } \\
\text { Island }\end{array}$ & $\mathrm{LH}$ & Minor 1985; Fagan 2004 & Greenspan; Baker & $\begin{array}{l}\text { Minor \& Greenspan (1995b); } \\
\text { Ogle et al. (2005) }\end{array}$ & 77 & 41 \\
\hline $35 \mathrm{CS} 5$ & Bandon Sandspit & $\mathrm{LH}, \mathrm{PH}$ & Cressman \& Collins 1952 & Tveskov & Tveskov $(2000)$ & 49 & 31 \\
\hline $35 \mathrm{CS} 61$ & Blue Barn & $\mathrm{MH}, \mathrm{LH}$ & Tveskov 2006 & Tveskov & Tveskov and Cohen (2007) & 209 & 14 \\
\hline $35 \mathrm{CS} 43$ & $\begin{array}{l}\text { Nah-so-mah (Old Town } \\
\text { Bandon) }\end{array}$ & $\mathrm{LH}$ & $\begin{array}{l}\text { Ross \& Hall 1978, 1986, 1988, 1990, } \\
\text { 1991, } 1993\end{array}$ & Hall & Hall (2001) & $\begin{array}{r}\text { not } \\
\text { reported }\end{array}$ & 870 \\
\hline $35 \mathrm{CU} 2$ & Cape Blanco & $\mathrm{MH}, \mathrm{LH}$ & Minor 1997 & Greenspan & Minor \& Greenspan (1998b) & 100 & 44 \\
\hline $35 \mathrm{CU} 160$ & Goat Island & $\mathrm{LH}$ & Gard 1989 & Gard & Gard (1990) & 152 & 78 \\
\hline
\end{tabular}

${ }^{1} \mathrm{MH}=$ Middle Holocene: 7500- 3000 years ago; LH= Late Holocene: 3000 years ago to contact era (Aikens et al. 2011); PH= Protohistoric (just before contact) ${ }^{2}$ Many of these sites were excavated multiple times; the excavations listed here are associated with the systematically analyzed bird assemblages.

${ }^{3} \mathrm{NSP}=$ Number of Specimens in the assemblage; NISP= Number of Identified Specimens (specimens identified more specifically than "bird") 
Table 4. Number of Identified Specimens (NISP) by major taxonomic groups of birds. ${ }^{1}$

\begin{tabular}{|c|c|c|c|c|c|c|c|c|c|c|}
\hline Taxonomic Name & Common Name & $\begin{array}{r}\text { Ind } \\
\mathrm{Pt}\end{array}$ & Dunes & $\begin{aligned} \text { Par- } \\
\text { Tee }\end{aligned}$ & $\begin{array}{r}\text { Palm } \\
\text { rose }\end{array}$ & $\begin{array}{r}\text { Ave } \\
\text { Q }\end{array}$ & $\begin{array}{r}\text { Ecola } \\
\text { Pt }\end{array}$ & $\begin{array}{l}\text { Net- } \\
\text { arts }\end{array}$ & $\begin{array}{l}\text { Boil } \\
\text { Bay }\end{array}$ & $\begin{array}{l}\text { Whl } \\
\text { Cve }\end{array}$ \\
\hline Anatidae & $\begin{array}{l}\text { Ducks, Geese, } \\
\text { Swans }\end{array}$ & 165 & 593 & 302 & 456 & 83 & 6 & 132 & 3 & 46 \\
\hline Phasianinae & $\begin{array}{l}\text { Domestic } \\
\text { Chicken }\end{array}$ & 44 & & & & & & & & \\
\hline Tetraoninae & Grouse & 2 & & & 4 & & & & & \\
\hline Podicipedidae & Grebes & 1 & 17 & 3 & 8 & 9 & 2 & 7 & & \\
\hline Columbidae & Pigeons & 1 & 12 & & & 1 & & & & \\
\hline Rallidae & Coots & 2 & & & & & & & & \\
\hline Gruidae & Cranes & & & & 1 & & & & & \\
\hline Haematopodidae & Oystercatcher & & & & & & & & & \\
\hline Charadriidae & Plovers & & & & & 1 & & & & \\
\hline Scolopacidae & Sandpipers & & & & 2 & 1 & & 2 & & \\
\hline Alcidae & $\begin{array}{l}\text { Auks (Murres, } \\
\text { Puffins) }\end{array}$ & & 811 & 181 & 80 & 220 & 10 & 89 & 77 & 15 \\
\hline Laridae & Gulls & & 97 & 40 & 82 & 26 & 2 & 51 & 4 & 12 \\
\hline Gaviidae & Loons & 16 & 60 & 19 & 15 & 6 & 1 & 33 & & 2 \\
\hline Diomedeidae & Albatrosses & & 71 & 22 & 28 & 7 & 4 & 64 & & 15 \\
\hline Procellaridae & $\begin{array}{l}\text { Fulmars, } \\
\text { Shearwaters }\end{array}$ & 2 & 508 & 131 & 52 & 55 & 16 & 40 & 33 & 6 \\
\hline Hydrobatidae & Storm-petrels & & & & & & 18 & & & \\
\hline oracidae & Cormorants & 2 & 22 & 46 & 59 & 5 & 7 & 36 & 2 & 8 \\
\hline Pelecanidae & Pelicans & & 3 & 1 & 4 & & & 15 & & \\
\hline Ardeidae & Herons & 3 & & & & & & 3 & & \\
\hline Pandionidae & Osprey & & & & & & & & & \\
\hline Accipitridae & Eagles, Hawks & 6 & 1 & 2 & 2 & 3 & 9 & 12 & & \\
\hline Strigidae & Owls & 2 & 1 & & 1 & & & 3 & & \\
\hline Alecedinidae & Kingfishers & 3 & & & & & & & & \\
\hline Picidae & Woodpeckers & & & & & 2 & & & & 1 \\
\hline Falconidae & Falcons & & & & 1 & & & & & \\
\hline Passeriformes & Perching Birds & 7 & 34 & 2 & 4 & 6 & 2 & 37 & & 1 \\
\hline Total NISP & & 256 & 2230 & 749 & 799 & 425 & 77 & 524 & 119 & 106 \\
\hline
\end{tabular}


Table 4. (Continued)

\begin{tabular}{|c|c|c|c|c|c|c|c|c|c|c|}
\hline Taxonomic Name & $\begin{array}{r}\mathrm{N} \\
\text { Yaq } \\
\mathrm{Hd} \\
\end{array}$ & $\begin{array}{l}\text { Yaq } \\
\mathrm{Hd}\end{array}$ & $\begin{array}{r}\text { Cape } \\
\text { Crk }\end{array}$ & $\begin{array}{r}\mathrm{Gd} \\
\mathrm{Frt} \\
\mathrm{Pt}\end{array}$ & $\begin{array}{r}\text { Gd } \\
\text { Frt } \\
\text { Cve } \\
\end{array}$ & $\begin{array}{l}\text { Bob } \\
\text { Crk }\end{array}$ & $\begin{array}{l}\text { Lily } \\
\text { Lke }\end{array}$ & $\begin{array}{l}\text { Tahk } \\
\text { Land }\end{array}$ & $\begin{array}{l}\text { Ump/ } \\
\text { Edn }\end{array}$ & $\begin{array}{r}\text { Hau- } \\
\text { ser }\end{array}$ \\
\hline Anatidae & 20 & 157 & 17 & & 13 & 2 & 8 & 151 & 1198 & 264 \\
\hline Phasianinae & & & 9 & & & & & & 8 & \\
\hline Tetraoninae & & 1 & & & & & & & & \\
\hline Podicipedidae & & 11 & & & & & & 11 & 18 & 10 \\
\hline Columbidae & & & & & & & & & & \\
\hline Rallidae & & & & & & & & 3 & & \\
\hline Gruidae & & & & & & & & & 1 & \\
\hline Haematopodidae & & & & & & & & & & \\
\hline Charadriidae & & & & & & & & & & 1 \\
\hline Scolopacidae & & & & & & & & & 11 & 2 \\
\hline Alcidae & 3 & 87 & 5 & 1 & & & & 10 & 1 & 76 \\
\hline Laridae & 9 & 34 & 7 & & 6 & 4 & & 9 & 45 & 13 \\
\hline Gaviidae & 4 & 23 & & 1 & & & & 14 & 86 & 26 \\
\hline Diomedeidae & & 92 & 4 & & & & & & 3 & \\
\hline Procellaridae & 1 & 194 & & & & & & 12 & 2 & 18 \\
\hline Hydrobatidae & & 13 & & & & & & & & \\
\hline Phalacrocoracidae & 73 & 93 & 28 & & & 1 & 231 & 21 & 94 & 26 \\
\hline Pelecanidae & & & & & & & & & 11 & \\
\hline Ardeidae & & & & & & & & 8 & 1 & \\
\hline Pandionidae & & & & & & & & & 3 & \\
\hline Accipitridae & 3 & & & & & & & & 44 & \\
\hline Strigidae & & & 3 & & & & & & 3 & \\
\hline Alecedinidae & & & & & & & & & & \\
\hline Picidae & & & & & & & & & 1 & \\
\hline Falconidae & & & & & & & & & 1 & \\
\hline Passeriformes & & 4 & 1 & & & 1 & & 5 & 22 & \\
\hline Total NISP & 113 & 709 & 74 & 2 & 19 & 8 & 239 & 244 & 1553 & 436 \\
\hline
\end{tabular}


Table 4. (Continued)

\begin{tabular}{|c|c|c|c|c|c|c|c|c|c|}
\hline Taxonomic Name & Koch & $\begin{array}{l}\text { Bald- } \\
\text { iyaka }\end{array}$ & $\begin{array}{c}\text { Ban- } \\
\text { don }\end{array}$ & $\begin{array}{l}\text { Blue } \\
\text { Barn }\end{array}$ & $\begin{array}{r}\text { Nah- } \\
\text { so- } \\
\text { mah }\end{array}$ & $\begin{array}{l}\text { Cape } \\
\text { Blnc }\end{array}$ & $\begin{array}{r}\text { Goat } \\
\text { Isl }^{2}\end{array}$ & $\begin{array}{r}\text { Grand } \\
\text { Total }\end{array}$ & $\begin{array}{l}\% \text { of } \\
\text { Ident- } \\
\text { ified }\end{array}$ \\
\hline Anatidae & 74 & 29 & 14 & 12 & 502 & & & 4247 & 43 \\
\hline Phasianinae & & & & & & & & 61 & 1 \\
\hline Tetraoninae & & & & & & & & 7 & $<1$ \\
\hline Podicipedidae & 2 & & & & 12 & & & 111 & 1 \\
\hline Columbidae & & & & & & & & 14 & $<1$ \\
\hline Rallidae & & & & & 22 & & & 27 & $<1$ \\
\hline Gruidae & & & & & & & & 2 & $<1$ \\
\hline Haematopodidae & & 3 & & & & & & 3 & $<1$ \\
\hline Charadriidae & & & & & 24 & & & 26 & $<1$ \\
\hline Scolopacidae & & & & & & & & 18 & $<1$ \\
\hline Alcidae & 3 & & & & 41 & 5 & 2 & 1717 & 17 \\
\hline Laridae & 10 & & 3 & & 47 & 1 & & 502 & 5 \\
\hline Gaviidae & 2 & 3 & 3 & & 25 & & & 339 & 3 \\
\hline Diomedeidae & & 2 & & & 11 & & & 323 & 3 \\
\hline Procellaridae & & & & 1 & & & & 1071 & 11 \\
\hline Hydrobatidae & & & & & & & 76 & 107 & 1 \\
\hline Phalacrocoracidae & 4 & 4 & & 1 & 130 & 38 & & 931 & 9 \\
\hline Pelecanidae & & & & & 1 & & & 35 & $<1$ \\
\hline Ardeidae & & & 1 & & 8 & & & 24 & $<1$ \\
\hline Pandionidae & & & & & & & & 3 & $<1$ \\
\hline Accipitridae & & & 10 & & 19 & & & 111 & 1 \\
\hline Strigidae & & & & & 10 & & & 23 & $<1$ \\
\hline Alecedinidae & & & & & & & & 3 & $<1$ \\
\hline Picidae & & & & & 3 & & & 7 & $<1$ \\
\hline Falconidae & & & & & & & & 2 & $<1$ \\
\hline Passeriformes & & & & & 15 & & & 141 & 1 \\
\hline Total NISP & 95 & 41 & 31 & 14 & 870 & 44 & 78 & 9855 & \\
\hline
\end{tabular}

${ }^{1}$ Subfamily identifications are shown for Phasianidae to distinguish grouse (which are native) from introduced chickens. All passerines are grouped to Order (Passeriformes) as these are less frequently identified to family level. At least three families of Passeriformes (Corvidae, Turbidae, and Cardinalidae) have been identified in Oregon coast sites. A small number of specimens identified only as "Charadriiformes" were excluded from this table for CLT47 $(n=1), \operatorname{DO} 130(n=1), \operatorname{LNC62}(n=7), \operatorname{LNC} 57(n=1)$, and LNC55 $(n=1)$.

${ }^{2}$ Gard (1990) concluded that the identified bird remains, storm-petrels (Oceanodroma spp.) and Tufted Puffin (Fratercula cirrhata), were naturally incorporated into the site, given that both taxa are burrow nesters currently breeding on Goat Island. Three unidentified fragments were deemed to be archaeological, rather than intrusive (given their context). 
Table 5: Number of Identified Specimens (NISP) for sites with $>100$ identified bird specimens. Percentages are shown in parentheses for major taxonomic groups (bold). More specific identifications are shown for the four most abundant families.

\begin{tabular}{|c|c|c|c|c|}
\hline Taxonomic Name & Common Name & Indian $\mathrm{Pt}$ & Dunes & Par-Tee \\
\hline Cygini & Swans & 35 & & \\
\hline Anserini & Geese & 32 & 51 & 6 \\
\hline Anatini & Dabbling Ducks & 17 & & 12 \\
\hline Aythyini & Bay Ducks/ Pochards & 1 & & \\
\hline Mergini $^{1}$ & Diving Sea Ducks & 4 & 464 & 231 \\
\hline Oxyurini & Stiff-tailed Ducks & & & \\
\hline Anatidae (unid.) & Unid. Anatids & 76 & 78 & 53 \\
\hline Anatidae Total & Ducks, Geese, Swans & $165(65)$ & $593(27)$ & $302(40)$ \\
\hline Podicipedidae & Grebes & $1(<1)$ & $17(1)$ & $3(<1)$ \\
\hline Uria aalge & Common Murre & & 594 & 181 \\
\hline Cepphus columba & Pigeon Guillemot & & & \\
\hline Brachyramphus marmoratus & Marbled Murrelet & & 8 & \\
\hline Synthliboramphus antiquus & Ancient Murrelet & & & \\
\hline Ptychoramphus aleuticus & Cassin's Auklet & & 128 & \\
\hline Cerorhinca monocerata & Rhinoceros Auklet & & 38 & \\
\hline Fratercula cirrhata & Tufted Puffin & & 13 & \\
\hline Alcidae (unid.) & Unid. Alcids & & 30 & \\
\hline Alcidae Total & Auks (Murres, Puffins) & & $811(36)$ & $181(24)$ \\
\hline Laridae & Gulls & & $97(4)$ & $40(5)$ \\
\hline Gaviidae & Loons & $16(6)$ & $60(3)$ & $19(3)$ \\
\hline Diomedidae & Albatross & & $71(3)$ & $22(3)$ \\
\hline Fulmarus glacialis & Northern Fulmar & & 38 & \\
\hline Ardenna (=Puffinus) spp. ${ }^{2}$ & Shearwaters & 2 & 453 & 130 \\
\hline Procellariidae (unid.) & Unid. Procellariids & & 17 & 1 \\
\hline Procellariidae Total & Fulmars, Shearwaters & $2(1)$ & $508(23)$ & $131(18)$ \\
\hline Phalacrocorax penicillatus & Brandt's Cormorant & & & 7 \\
\hline Phalacrocorax auritus & Double-crested Corm. & & & 4 \\
\hline Phalacrocorax pelagicus & Pelagic Cormorant & & & 27 \\
\hline Phalacrocorax spp. (unid.) & Unid. Cormorant & 2 & 22 & 8 \\
\hline Phalacrocoracidae Total & Cormorants & $2(1)$ & $22(1)$ & $46(6)$ \\
\hline Other Birds & & $70(27)$ & $51(2)$ & $5(1)$ \\
\hline Total NISP & & 256 & 2230 & 749 \\
\hline
\end{tabular}


Table 5. (Continued)

\begin{tabular}{|c|c|c|c|c|c|c|c|}
\hline Taxonomic Name & Palmrose & Ave Q & Netarts & Boil Bay & Whl Cve & N Yaq Hd & Yaq Hd \\
\hline Cygini & & & 2 & & & & \\
\hline Anserini & 20 & 9 & 16 & & 4 & & 1 \\
\hline Anatini & 17 & 3 & 18 & & & & 1 \\
\hline Aythyini & 6 & 1 & & & & 1 & \\
\hline $\begin{array}{l}\text { Mergini }^{1} \\
\text { Oxyurini }\end{array}$ & 319 & 13 & 86 & 3 & 28 & & 63 \\
\hline Anatidae (unid.) & 94 & 57 & 10 & & 14 & 19 & 92 \\
\hline Anatidae Total & $456(57)$ & $83(20)$ & $132(25)$ & $3(3)$ & $46(43)$ & $20(18)$ & $157(22)$ \\
\hline Podicipedidae & $8(1)$ & $9(2)$ & $7(1)$ & & & & $11(2)$ \\
\hline Uria aalge & 64 & 214 & 50 & & 8 & 3 & 33 \\
\hline Cepphus columba & & & 1 & & & & \\
\hline Brachyramphus marmoratus & 3 & 2 & 4 & & & & 9 \\
\hline \multicolumn{8}{|l|}{ Synthliboramphus antiquus } \\
\hline Ptychoramphus aleuticus & 1 & & 4 & & & & 1 \\
\hline Cerorhinca monocerata & & 2 & 13 & 77 & 2 & & 11 \\
\hline Fratercula cirrhata & & & 17 & & 3 & & 19 \\
\hline Alcidae (unid.) & 12 & 2 & & & 2 & & 14 \\
\hline Alcidae Total & $80(10)$ & $220(52)$ & 89 (17) & $77(65)$ & $15(14)$ & $3(3)$ & $87(12)$ \\
\hline Laridae & $82(10)$ & $26(6)$ & $51(10)$ & $4(3)$ & $12(11)$ & $9(8)$ & $34(5)$ \\
\hline Gaviidae & $15(2)$ & $6(1)$ & $33(6)$ & & $2(2)$ & $4(4)$ & $23(3)$ \\
\hline Diomedidae & $28(4)$ & $7(2)$ & $64(12)$ & & $15(14)$ & & $92(13)$ \\
\hline Fulmarus glacialis & 2 & 5 & 15 & & 3 & 1 & 155 \\
\hline Ardenna (=Puffinus) spp. ${ }^{2}$ & 49 & 50 & 6 & 33 & 3 & & 37 \\
\hline Procellariidae (unid.) & 1 & & 19 & & & & 2 \\
\hline Procellariidae Total & $52(7)$ & $55(13)$ & $40(8)$ & $33(28)$ & $6(6)$ & $1(1)$ & $194(27)$ \\
\hline Phalacrocorax penicillatus & 14 & & 1 & & & & \\
\hline Phalacrocorax auritus & 7 & 3 & & & 1 & & \\
\hline Phalacrocorax pelagicus & 8 & & 4 & & 4 & & \\
\hline Phalacrocorax spp. (unid.) & 30 & 2 & 31 & 2 & 3 & 73 & 93 \\
\hline Phalacrocoracidae Total & $59(7)$ & $5(1)$ & $36(7)$ & $2(2)$ & $8(8)$ & $73(65)$ & $93(13)$ \\
\hline Other Birds & $19(2)$ & $14(3)$ & $72(14)$ & & $2(2)$ & $3(3)$ & $18(3)$ \\
\hline Total NISP & 799 & 425 & 524 & 119 & 106 & 113 & 709 \\
\hline
\end{tabular}


Table 5. (Continued)

\begin{tabular}{|c|c|c|c|c|c|c|}
\hline Taxonomic Name & Lily Lke & Tahk Land & Ump/Edn & Hauser & Nah-so-mah & Total $(\%)$ \\
\hline$\overline{\text { Cygini }}$ & & & & & 7 & 44 \\
\hline Anserini & & 4 & 74 & 71 & 18 & 306 \\
\hline Anatini & & 1 & 80 & 5 & 314 & 468 \\
\hline Aythyini & & & 132 & & 79 & 220 \\
\hline Mergini $^{1}$ & 3 & 16 & 570 & 41 & 64 & 1905 \\
\hline Oxyurini & & & 2 & & & 2 \\
\hline Anatidae (unid.) & 5 & 130 & 340 & 147 & 20 & 1135 \\
\hline Anatidae Total & $8(3)$ & $151(62)$ & $1198(77)$ & $264(61)$ & $502(58)$ & $4080(44)$ \\
\hline Podicipedidae & & $11(5)$ & $18(1)$ & $10(2)$ & $12(1)$ & $107(1)$ \\
\hline Uria aalge & & 10 & & 34 & 34 & 1225 \\
\hline Cepphus columba & & & & & 1 & 2 \\
\hline Brachyramphus marmoratus & & & & 1 & & 27 \\
\hline Synthliboramphus antiquus & & & & 24 & & 24 \\
\hline Ptychoramphus aleuticus & & & & & 6 & 140 \\
\hline Cerorhinca monocerata & & & & & & 143 \\
\hline Fratercula cirrhata & & & & & & 52 \\
\hline Alcidae (unid.) & & & 1 & 17 & & 78 \\
\hline Alcidae Total & & $10(4)$ & $1(<1)$ & $76(17)$ & $41(5)$ & $1691(18)$ \\
\hline Laridae & & $9(4)$ & $45(3)$ & $13(3)$ & $47(5)$ & $469(5)$ \\
\hline Gaviidae & & $14(6)$ & $86(6)$ & $26(6)$ & $25(3)$ & $329(4)$ \\
\hline Diomedidae & & & $3(<1)$ & & $11(1)$ & $313(3)$ \\
\hline Fulmarus glacialis & & & 1 & & & 220 \\
\hline Ardenna (=Puffinus) spp. ${ }^{2}$ & & 12 & & 18 & & 793 \\
\hline Procellariidae (unid.) & & & 1 & & & 41 \\
\hline Procellariidae Total & & $12(5)$ & $2(<1)$ & $18(4)$ & & $1054(11)$ \\
\hline Phalacrocorax penicillatus & & & 1 & 3 & & 26 \\
\hline Phalacrocorax auritus & & & 28 & 3 & & 46 \\
\hline Phalacrocorax pelagicus & & & 11 & & & 54 \\
\hline Phalacrocorax spp. (unid.) & 231 & 21 & 54 & 20 & 130 & 722 \\
\hline Phalacrocoracidae Total & $231(97)$ & $21(9)$ & $94(6)$ & $26(6)$ & $130(15)$ & $848(9)$ \\
\hline Other Birds & & $16(7)$ & $106(7)$ & $3(1)$ & $102(12)$ & $481(5)$ \\
\hline Total NISP & 239 & 244 & 1553 & 436 & 870 & 9372 \\
\hline
\end{tabular}

${ }^{1}$ Of those Mergini identified to species ( $\left.\mathrm{n}=1823\right), 93 \%(\mathrm{n}=1701)$ were Scoters (Melanitta $\mathrm{spp}$.).

${ }^{2}$ Of those shearwaters identified to species $(n=555), 99 \%(n=548)$ were Sooty Shearwaters (Ardenna grisea). 
Table 6. Pearson correlation coefficients for each pair of archaeological bird assemblages.

\begin{tabular}{|c|c|c|c|c|c|c|c|c|c|c|c|c|c|c|c|c|}
\hline & & $\begin{array}{l}\text { CLT- } \\
34 \\
\end{array}$ & $\begin{array}{l}\text { CLT- } \\
27 \\
\end{array}$ & $\begin{array}{l}\text { CLT- } \\
13\end{array}$ & $\begin{array}{l}\text { CLT- } \\
47 \\
\end{array}$ & $\begin{array}{l}\text { CLT- } \\
20\end{array}$ & TI-1 & $\begin{array}{l}\text { LNC- } \\
45 \\
\end{array}$ & $\begin{array}{l}\text { LNC- } \\
60 \\
\end{array}$ & $\begin{array}{l}\text { LNC- } \\
50\end{array}$ & $\begin{array}{l}\text { LNC- } \\
62 \\
\end{array}$ & $\begin{array}{l}\text { LA- } \\
19 \\
\end{array}$ & $\begin{array}{l}\text { DO- } \\
130 \\
\end{array}$ & $\begin{array}{l}\text { DO- } \\
83 \\
\end{array}$ & $\begin{array}{l}\text { CS- } \\
114 \\
\end{array}$ & $\begin{array}{l}\text { CS- } \\
43 \\
\end{array}$ \\
\hline Indian Point & CLT-34 & & 0.63 & 0.74 & 0.92 & 0.82 & 0.81 & -0.11 & 0.85 & 0.06 & 0.35 & -.18 & 0.94 & 0.95 & 0.93 & 0.94 \\
\hline Dunes & CLT-27 & & & 0.92 & 0.56 & 0.88 & 0.75 & 0.83 & 0.61 & -0.09 & 0.70 & -.13 & 0.46 & 0.40 & 0.64 & 0.40 \\
\hline Avenue Q & CLT-13 & & & & 0.35 & 0.70 & 0.64 & 0.92 & 0.44 & -0.10 & 0.41 & -.12 & 0.23 & 0.18 & 0.46 & 0.21 \\
\hline Palmrose & CLT-47 & & & & & 0.88 & 0.85 & 0.03 & 0.96 & 0.22 & 0.57 & 0.00 & 0.98 & 0.97 & 0.98 & 0.96 \\
\hline Par-Tee & CLT-20 & & & & & & 0.89 & 0.48 & 0.87 & 0.13 & 0.76 & 0.02 & 0.81 & 0.77 & 0.91 & 0.77 \\
\hline Netarts & TI-1 & & & & & & & 0.36 & 0.94 & 0.10 & 0.62 & -.04 & 0.76 & 0.75 & 0.86 & 0.75 \\
\hline Boiler Bay & LNC-45 & & & & & & & & 0.13 & -0.14 & 0.39 & 0.50 & -.09 & -.15 & 0.14 & -.12 \\
\hline Whale Cove & LNC-60 & & & & & & & & & 0.20 & 0.62 & 0.00 & 0.89 & 0.89 & 0.92 & 0.89 \\
\hline N Yaquina & LNC-50 & & & & & & & & & & 0.25 & 0.97 & 0.24 & 0.21 & 0.19 & 0.36 \\
\hline Yaquina & LNC-62 & & & & & & & & & & & 0.33 & 0.50 & 0.44 & 0.53 & 0.45 \\
\hline Lily Lake & LA-19 & & & & & & & & & & & & -.01 & -.06 & -.03 & 0.11 \\
\hline Tahkenitch & DO-130 & & & & & & & & & & & & & 0.99 & 0.97 & 0.98 \\
\hline Ump/Eden & DO-83 & & & & & & & & & & & & & & 0.95 & 0.98 \\
\hline Hauser & CS-114 & & & & & & & & & & & & & & & 0.94 \\
\hline Nah-so-mah & $\mathrm{CS}-43$ & & & & & & & & & & & & & & & \\
\hline
\end{tabular}


Table 7. Oregon coast bird assemblages in order of taxonomic diversity (measured by reciprocal of Simpson's Index).

\begin{tabular}{clcc}
\hline $\begin{array}{c}\text { Site \# } \\
\text { 35- }\end{array}$ & \multicolumn{1}{c}{ Site Name } & $\begin{array}{c}\text { Reciprocal of } \\
\text { Simpson's Index }\end{array}$ & Habitat \\
\hline TI-1 & Netarts & 7.305 & riverine/estuarine \\
LNC-62 & Yaquina & 5.662 & outer coast \\
LNC-60 & Whale Cove & 3.991 & outer coast \\
CLT-27 & Dunes & 3.863 & intermediate \\
CLT-20 & Par-Tee & 3.850 & intermediate \\
CLT-13 & Avenue Q & 3.050 & intermediate \\
CLT-47 & Palmrose & 2.796 & intermediate \\
CS-43 & Nah-so-mah & 2.760 & riverine/estuarine \\
DO-130 & Tahkenitch & 2.490 & riverine/estuarine \\
CS-114 & Hauser & 2.455 & riverine/estuarine \\
CLT-34 & Indian Point & 2.377 & riverine/estuarine \\
LNC-50 & North Yaquina & 2.185 & outer coast \\
LNC-45 & Boiler Bay & 2.010 & outer coast \\
DO-83 & Umpqua/Eden & 1.656 & riverine/estuarine \\
LA-19 & Lily Lake & 1.069 & intermediate \\
\hline
\end{tabular}


Table 8. Correlation between taxon-specific NISP at each of 15 archeological sites and corresponding beached bird taxonomic assemblages from the COASST dataset. COASST sites: number of data collection sites within $20 \mathrm{~km}$ of the archeological site. Significant regressions are indicated in bold.

\begin{tabular}{lccccc}
\hline & COASST & Pearson's & \multicolumn{2}{c}{ Regression } & \\
Archeological Site & Sites & $\mathrm{R}$ & Coefficient & \multicolumn{1}{c}{$95 \%$ CI } \\
\hline Indian Point & 5 & -0.33 & -0.38 & -0.89 & 0.12 \\
Dunes & $\mathbf{1 3}$ & $\mathbf{0 . 5 8}$ & $\mathbf{0 . 5 9}$ & $\mathbf{0 . 2 1}$ & $\mathbf{0 . 9 7}$ \\
Par-Tee & $\mathbf{1 4}$ & $\mathbf{0 . 4 5}$ & $\mathbf{0 . 5 0}$ & $\mathbf{0 . 0 4}$ & $\mathbf{0 . 9 6}$ \\
Palmrose & 14 & 0.30 & 0.31 & -0.15 & 0.77 \\
Avenue Q & $\mathbf{1 5}$ & $\mathbf{0 . 7 6}$ & $\mathbf{0 . 8 3}$ & $\mathbf{0 . 5 0}$ & $\mathbf{1 . 1 6}$ \\
Netarts & $\mathbf{9}$ & $\mathbf{0 . 4 3}$ & $\mathbf{0 . 3 5}$ & $\mathbf{0 . 0 1}$ & $\mathbf{0 . 6 9}$ \\
Boiler Bay & 16 & 0.15 & 0.19 & -0.39 & 0.77 \\
Whale Cove & 17 & 0.37 & 0.38 & -0.06 & 0.82 \\
North Yaquina & 15 & 0.39 & 0.49 & -0.05 & 1.04 \\
Yaquina & $\mathbf{1 7}$ & $\mathbf{0 . 5 2}$ & $\mathbf{0 . 5 0}$ & $\mathbf{0 . 1 2}$ & $\mathbf{0 . 8 7}$ \\
Lily Lake & 11 & 0.16 & 0.21 & -0.41 & 0.83 \\
Tahkenitch & $\mathbf{4}$ & $\mathbf{0 . 4 2}$ & $\mathbf{0 . 4 5}$ & $\mathbf{0 . 0 0}$ & $\mathbf{0 . 9 0}$ \\
Umpqua/Eden & 4 & -0.13 & -0.15 & -0.66 & 0.37 \\
Hauser & 8 & 0.25 & 0.25 & -0.21 & 0.71 \\
Nah-so-mah & 14 & 0.06 & 0.06 & -0.42 & 0.55 \\
\hline
\end{tabular}


Supplemental Table 1. Proximity and abundance of colony breeding birds (modern data from Naughton et al. 2007) to Oregon archaeological sites. Note that the numbers within a $20 \mathrm{~km}$ distance are cumulative (i.e., added to the numbers within a $10 \mathrm{~km}$ distance).

\begin{tabular}{|c|c|c|c|c|c|c|}
\hline & \multirow{3}{*}{ Site Name } & \multicolumn{4}{|c|}{ Breeding Birds } & Notes on archaeological assemblage \\
\hline \multirow[t]{2}{*}{ Site \# } & & \multicolumn{2}{|c|}{ colonies w/in $10 \mathrm{~km}$} & \multicolumn{2}{|c|}{ colonies w/in $20 \mathrm{~km}$} & \\
\hline & & $\#$ & Taxon & \# & Taxon & \\
\hline \multirow[t]{3}{*}{ CLT-34 } & Indian Point & 3942 & $\mathrm{La}$ & 3942 & $\mathrm{La}$ & \multirow{3}{*}{$\begin{array}{l}\text { gulls not represented at all, very few } \\
(0.8 \%) \text { cormorants }\end{array}$} \\
\hline & & 766 & $\mathrm{Ph}$ au & 1026 & $\mathrm{Ph} \mathrm{au}$ & \\
\hline & & & & 284 & Ph pel & \\
\hline \multirow[t]{3}{*}{ CLT-27 } & Dunes & & & 69987 & Ur aa & \multirow{3}{*}{$\begin{array}{l}\text { all colonies to south of the site; largest are } \\
\text { Bird Rocks and Sea Lion Rocks }(16 \mathrm{~km} \\
\text { away). } 27 \% \text { murres. }\end{array}$} \\
\hline & & & & 2444 & $\mathrm{Ph}$ pe & \\
\hline & & & & 315 & $\mathrm{La}$ & \\
\hline \multirow[t]{5}{*}{ CLT-13 } & Avenue $\mathrm{Q}$ & 69987 & Ur aa & 70286 & Ur aa & \multirow{4}{*}{$\begin{array}{l}\text { all colonies to south of the site; largest are } \\
\text { Bird Rocks and Sea Lion Rocks }(8-9 \mathrm{~km} \\
\text { away). Highest proportion of murres } \\
(50 \%) \text { of CLT sites }\end{array}$} \\
\hline & & 2444 & $\mathrm{Ph}$ pe & 3664 & $\mathrm{Ph}$ pe & \\
\hline & & 315 & $\mathrm{La}$ & 1574 & $\mathrm{La}$ & \\
\hline & & & & 612 & Fr ci & \\
\hline & & & & 366 & Ph pel & \\
\hline \multirow[t]{5}{*}{ CLT-47 } & Palmrose & 69987 & Ur aa & 73197 & Ur aa & \multirow{3}{*}{$\begin{array}{l}\text { all colonies to south of the site; largest are } \\
\text { Bird Rocks and Sea Lion Rocks }(7-8 \mathrm{~km} \\
\text { away). } 8 \% \text { murres. }\end{array}$} \\
\hline & & 2444 & $\mathrm{Ph}$ pe & 4406 & $\mathrm{Ph}$ pe & \\
\hline & & 315 & $\mathrm{La}$ & 1574 & $\mathrm{La}$ & \\
\hline & & & & 612 & Fr ci & \\
\hline & & & & 366 & Ph pel & \\
\hline \multirow[t]{5}{*}{ CLT-20 } & Par-Tee & 69987 & Ur aa & 73197 & Ur aa & \multirow{3}{*}{$\begin{array}{l}\text { all colonies to south of the site; largest are } \\
\text { Bird Rocks and Sea Lion Rocks }(7-8 \mathrm{~km} \\
\text { away). } 24 \% \text { murres. }\end{array}$} \\
\hline & & 2444 & $\mathrm{Ph}$ pe & 4406 & Ph pe & \\
\hline & & 315 & $\mathrm{La}$ & 1574 & La & \\
\hline & & & & 612 & Fr ci & \\
\hline & & & & 366 & $\mathrm{Ph}$ pel & \\
\hline & & & & & & \\
\hline TI-1 & Netarts & 241763 & Ur aa & 241763 & Ur aa & large colonies at Three Arch Rocks are $<6$ \\
\hline
\end{tabular}




\begin{tabular}{|c|c|c|c|c|c|c|}
\hline & & 25104 & Oc le & 25104 & Oc le & \multirow{6}{*}{$\begin{array}{l}\mathrm{km} \text { away. colonies to north } \& \text { south. } 25 \% \\
\text { anatids, } 10 \% \text { murres. }\end{array}$} \\
\hline & & 3030 & Fr ci & 3030 & Fr ci & \\
\hline & & 2518 & $\mathrm{Ph}$ pe & 2786 & $\mathrm{Ph}$ pe & \\
\hline & & 1490 & $\mathrm{La}$ & 1490 & $\mathrm{La}$ & \\
\hline & & 924 & $\mathrm{Ph} \mathrm{au}$ & 1362 & $\mathrm{Ph} \mathrm{au}$ & \\
\hline & & 178 & $\mathrm{Ph}$ pel & 178 & $\mathrm{Ph}$ pel & \\
\hline \multirow[t]{4}{*}{ LNC-45 } & Boiler Bay & 69737 & Ur aa & 70680 & Ur aa & \multirow{4}{*}{$\begin{array}{l}\text { largest colonies at Yaquina Head, } 17 \mathrm{~km} \\
\text { away. } 65 \% \text { rhinoceros auklets. }\end{array}$} \\
\hline & & 2304 & $\mathrm{Ph}$ pe & 2442 & $\mathrm{Ph}$ pe & \\
\hline & & 612 & $\mathrm{Ph}$ pel & 982 & $\mathrm{Ph}$ pel & \\
\hline & & 290 & $\mathrm{La}$ & 578 & $\mathrm{La}$ & \\
\hline \multirow[t]{4}{*}{ LNC-60 } & Whale Cove & 69737 & Ur aa & 70680 & Ur aa & \multirow{4}{*}{$\begin{array}{l}\text { largest colonies at Yaquina Head, } 12.5 \mathrm{~km} \\
\text { away. }\end{array}$} \\
\hline & & 2826 & $\mathrm{Ph}$ pe & 2964 & $\mathrm{Ph}$ pe & \\
\hline & & 1830 & $\mathrm{Ph}$ pel & 2200 & $\mathrm{Ph}$ pel & \\
\hline & & & & 288 & $\mathrm{La}$ & \\
\hline \multirow[t]{4}{*}{ LNC-50 } & North Yaquina Head & 69737 & Ur aa & 69737 & Ur aa & \multirow{4}{*}{$\begin{array}{l}\text { adjacent to large Yaquina Head colony, } \\
\text { from which } 98 \% \text { of the birds within } 10 \mathrm{~km} \\
\text { derive; no addition within } 20 \mathrm{~km} .65 \% \\
\text { cormorants. }\end{array}$} \\
\hline & & 2826 & $\mathrm{Ph}$ pe & 2826 & $\mathrm{Ph}$ pe & \\
\hline & & 1830 & $\mathrm{Ph}$ pel & 1830 & $\mathrm{Ph}$ pel & \\
\hline & & 124 & $\mathrm{La}$ & 124 & $\mathrm{La}$ & \\
\hline \multirow[t]{4}{*}{ LNC-62 } & Yaquina Head & 69737 & Ur aa & 69737 & Ur aa & \multirow{4}{*}{$\begin{array}{l}\text { adjacent to large Yaquina Head colony, } \\
\text { from which } 98 \% \text { of the birds within } 10 \mathrm{~km} \\
\text { derive; no addition within } 20 \mathrm{~km} .27 \% \\
\text { procellarids. }\end{array}$} \\
\hline & & 2826 & $\mathrm{Ph}$ pe & 2826 & $\mathrm{Ph}$ pe & \\
\hline & & 1830 & $\mathrm{Ph}$ pel & 1830 & $\mathrm{Ph}$ pel & \\
\hline & & 124 & $\mathrm{La}$ & 124 & $\mathrm{La}$ & \\
\hline \multirow[t]{8}{*}{ LA-19 } & Lily Lake & 3238 & $\mathrm{Ph}$ pe & 3488 & $\mathrm{Ph}$ pe & \multirow{7}{*}{$\begin{array}{l}\text { The largest colonies are Heceta Head } \\
\text { South }(4.5 \mathrm{~km} \text { away) and Sea Lion Caves } \\
\text { Headlands ( }<3 \mathrm{~km} \text { away). } 97 \% \text { cormorants }\end{array}$} \\
\hline & & 2178 & Ur aa & 2178 & Ur aa & \\
\hline & & 260 & $\mathrm{La}$ & 410 & $\mathrm{La}$ & \\
\hline & & 250 & $\mathrm{Ph}$ pel & 384 & Ph pel & \\
\hline & & 159 & Ce co & 159 & Ce co & \\
\hline & & 100 & $\mathrm{Ph} \mathrm{au}$ & 250 & $\mathrm{Ph}$ au & \\
\hline & & 100 & Oc le & 100 & Oc le & \\
\hline & & & & & & \\
\hline DO-130 & Tahkenitch & & & 1128 & $\mathrm{Ph}$ au & Not close to large colonies; $62 \%$ anatids. \\
\hline
\end{tabular}




\begin{tabular}{|c|c|c|c|c|c|c|}
\hline DO-83 & Umnqua/Eden & & & 1128 & $\mathrm{Ph}$ aul & Not close to laroe coloniec. $77^{\circ}$ o anatids \\
\hline & & & & & & \\
\hline \multirow[t]{6}{*}{ CS-114 } & Hauser & 518 & $\mathrm{Ph}$ au & 732 & $\mathrm{Ph}$ au & \multirow{6}{*}{$\begin{array}{l}\text { Not close to seabird colonies; } 61 \% \text { anatids, } \\
8 \% \text { murres. }\end{array}$} \\
\hline & & & & 704 & Ph pe & \\
\hline & & & & 292 & $\mathrm{La}$ & \\
\hline & & & & 179 & Ur aa & \\
\hline & & & & 118 & Ph pel & \\
\hline & & & & 114 & Ce co & \\
\hline \multirow{6}{*}{ CS-43 } & Nah-so-mah & 62862 & Ur aa & 62862 & Ur aa & \multirow{5}{*}{$\begin{array}{l}\text { North Coquille Point Rock and Cat \& } \\
\text { Kittens Rock are within } 3 \mathrm{~km} .58 \% \\
\text { anatids, } 15 \% \text { cormorants, } 4 \% \text { murres. }\end{array}$} \\
\hline & & 2372 & $\mathrm{Ph}$ pe & 2372 & $\mathrm{Ph}$ pe & \\
\hline & & 1482 & $\mathrm{La}$ & 1482 & $\mathrm{La}$ & \\
\hline & & 126 & Ph pel & 602 & Ph pel & \\
\hline & & 200 & Oc le & 200 & Oc le & \\
\hline & $\mathrm{C}_{\mathrm{C}}$ & & - & & 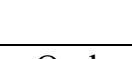 & \\
\hline
\end{tabular}

